\title{
Myeloid-specific genetic ablation of ATP-binding cassette transporter ABCA1 is protective against cancer
}

\author{
Maryam Zamanian-Daryoush ${ }^{1}$, Daniel J. Lindner ${ }^{2}$, Joseph A. DiDonato ${ }^{1}$, Matthew \\ Wagner $^{1}$, Jennifer Buffa ${ }^{1}$, Patricia Rayman ${ }^{3}$, John S. Parks ${ }^{4}$, Marit Westerterp ${ }^{5}$, \\ Alan R. Tall ${ }^{5}$ and Stanley L. Hazen ${ }^{1,6}$ \\ ${ }^{1}$ Department of Cellular \& Molecular Medicine, Cleveland Clinic, Cleveland, $\mathrm{OH} 44195$, USA \\ ${ }^{2}$ Taussig Cancer Institute, Cleveland Clinic, Cleveland, OH 44195, USA \\ ${ }^{3}$ Department of Immunology, Cleveland Clinic, Cleveland, OH 44195, USA \\ ${ }^{4}$ Department of Internal Medicine, Section on Molecular Medicine, Wake Forest School of Medicine, Winston-Salem, NC 27157, USA \\ ${ }^{5}$ Department of Medicine, Columbia University, College of Physicians and Surgeons 8-401, New York, NY 10032, USA \\ ${ }^{6}$ Department of Cardiovascular Medicine, Cleveland Clinic, Cleveland, OH 44195, USA \\ Correspondence to: Stanley L. Hazen, email: hazens@ccf.org \\ Keywords: cancer, apolipoprotein, myeloid cell, cholesterol, ABC transporter \\ Received: March 18, $2016 \quad$ Accepted: May 23, $2017 \quad$ Published: June 27, 2017 \\ Copyright: Zamanian-Daryoush et al. This is an open-access article distributed under the terms of the Creative Commons Attribution \\ License 3.0 (CC BY 3.0), which permits unrestricted use, distribution, and reproduction in any medium, provided the original author \\ and source are credited.
}

\section{ABSTRACT}

Increased circulating levels of apolipoprotein A-I (apoA-I), the major protein of high-density lipoprotein (HDL), by genetic manipulation or infusion, protects against melanoma growth and metastasis. Herein, we explored potential roles in melanoma tumorigenesis for host scavenger receptor class B, type 1 (SR-B1), and ATP-binding cassette transporters A1 (ABCA1) and G1 (ABCG1), all mediators of apoA-I and HDL sterol and lipid transport function. In a syngeneic murine melanoma tumor model, B16F10, mice with global deletion of SR-B1 expression exhibited increased plasma HDL cholesterol (HDLC) levels and decreased tumor volume, indicating host SR-B1 does not directly contribute to HDL-associated anti-tumor activity. In mice with myeloid-specific loss of ABCA1 (Abca1 $\left.1^{-M / M} ; A 1^{-M /-M}\right)$, tumor growth was inhibited by 4.8-fold relative to wild type (WT) animals. $A b c g 1^{-M / M}\left(G^{-M /-M}\right)$ animals were also protected by 2.5 -fold relative to WT, with no further inhibition of tumor growth in Abca1/Abcg1 myeloid-specific double knockout animals (DKO). Analyses of tumorinfiltrating immune cells revealed a correlation between tumor protection and decreased presence of the immune suppressive myeloid-derived suppressor cell (MDSC) subsets, $L y-6 G^{+} \mathrm{Ly}-6 \mathrm{C}^{\mathrm{LO}}$ and $\mathrm{Ly}-6 \mathrm{G}^{\mathrm{ne}} \mathrm{Ly}-6 \mathrm{C}^{\mathrm{Hi}}$ cells. The growth of the syngeneic MB49 murine bladder cancer cells was also inhibited in $\mathrm{A1}^{-\mathrm{M} / \mathrm{M}}$ mice. Collectively, our studies provide further evidence for an immune modulatory role for cholesterol homeostasis pathways in cancer.

\section{INTRODUCTION}

Previously, we reported an anti-tumorigenic activity for apoA-I and HDL against melanoma [1]. Mice genetically manipulated to express human apoA-I (apoA-I Tg) were protected from tumor growth and metastases, whereas
apoA-I-deficient (apoA-I KO) animals exhibited increased susceptibility to tumor proliferation [1]. Therapeutic delivery of human apoA-I into mice demonstrated antitumor activity in both established syngeneic mouse and xenograft human melanoma tumors. Both innate and adaptive immune arms were required for complete apoA-I 
anti-tumor activity, which was enabled in part through modulation of tumor infiltrating immune cells [1].

The athero-protective activities of HDL, namely lipid efflux and anti-inflammatory effects, are in major part thought to be mediated by the three known HDL or apoA-I receptors: ATP-binding cassette (ABC) transporters $\mathrm{A} 1$ (ABCA1) and $\mathrm{G} 1$ (ABCG1), and the scavenger receptor class B, type 1 (SR-B1) [2-4]. ABCA1 effluxes excess cholesterol and phospholipid to lipidpoor apoA-I, the predominant protein in $\operatorname{HDL}[5,6]$, whereas ABCG1 mediates cholesterol and lipid transport to an already assembled HDL particle [7-9]. Efflux activity of ABCA1 initiates HDL assembly and defects in ABCA1-mediated cholesterol efflux lead to nearly non-detectable plasma HDL cholesterol (HDLc) levels in the mouse $[10,11]$ or Tangier disease in humans [1215]. ABCA1 and ABCG1 are known to regulate several biological functions of hematopoietic cells. For example, mice deficient in ABCA1 and ABCG1 display hyperproliferation of hematopoietic stem and progenitor cells (HSPCs), with specific expansion of the myeloid and granulocyte macrophage progenitors [2]. This expansion leads to increased mobilization and activation of myeloid cells, resulting in monocytosis and neutrophilia. Genetic knockdown of ABCA1 and ABCG1 also led to increased surface expression of Toll-like receptor 4 (TLR4) and heightened inflammatory gene expression $[2,16]$. These observed effects were correlated with cholesterol accumulation in the transporter-deficient cells. Significantly, transplantation of bone marrow cells with genetic knockout of $A b c a l$ and $A b c g l$ into mouse models prone to developing atherosclerosis resulted in accelerated atherosclerosis, underscoring an athero-protective role for these transporters in myeloid cells [2-4]. ABCA1 has been shown to possess anti-inflammatory activity, presumably via its cholesterol effluxing capacity to apoA-I [17]. ABCG1 similarly has anti-inflammatory activity, and is even more potent than $\mathrm{ABCA} 1$ in modulating cholesterol levels in the plasma membrane [16]. SR-B1, encoded by $S c a r b 1$, is the primary receptor for selective uptake of cholesteryl ester from HDL particles, and has also been reported to have an anti-inflammatory function in macrophages by suppressing Toll-like receptor-4 (TLR4) and nuclear factor- $\mathrm{\kappa B}(\mathrm{NF}-\mathrm{\kappa B})$ signaling pathways [18].

In cancer cells, pharmacological and genetic evidence suggest a tumor-promoting role for cholesterol [19], and a tumor-inhibitory role for cholesterol efflux pathways [20]. For example, in prostate cancer cells inhibition of ABCA1, which effluxes cholesterol, resulted in tumor progression [19]. Conversely, elimination of SRB1 in breast cancer cells, which overexpress this receptor, lead to inhibition in tumor growth, suggestive of a tumor permissive role for SR-B1 in cancer cells [21].

In contrast to their role in some cancer cells, cholesterol efflux transporters appear to promote a tumor-supportive function in immune cells. Tumor- mediated immune suppression is orchestrated by a number of infiltrating immune cell types including tumor associated macrophages (TAMs) and myeloid derived suppressor cells (MDSCs). TAMs and MDSCs both help promote tumor angiogenesis and metastasis, as well as tumor immune evasion. MDSCs are functionally and morphologically heterogeneous immature cell populations that fail to differentiate into mature dendritic cells, granulocytes, or macrophages, and are reported to inhibit the function of T cells, natural killer (NK) cells and other immune cells by different mechanisms [22]. Two main subsets of MDSCs have been defined: polymorphonuclear - MDSCs (Ly-6G $\left.\mathrm{G}^{+} \mathrm{Ly}-6 \mathrm{C}^{\mathrm{Lo}}\right)$, which are granulocytic in appearance; and monocytic MDSCs (Ly-6 $\mathrm{G}^{\mathrm{neg}} \mathrm{Ly}-6 \mathrm{C}^{\mathrm{Hi}}$ ) [23]. The anti-tumor function of apoA-I and HDL in the murine B16F10 melanoma tumor model is associated with changes in MDSCs and TAMs; however, the receptors involved and their impact on host immune surveillance remain unclear [1].

In a recent study, global and myeloid deficiency of ABCG1 was shown to be associated with reduced melanoma and bladder tumor growth in mice fed a "western"-type diet [24]. However, the functional role for alternative cholesterol efflux transporters, ABCA1 and SR-B1, in tumor growth and host immune surveillance, has not yet been reported. In this study we investigated the role of host cholesterol transporters ABCA1, ABCG1, and the HDL receptor SR-B1, on melanoma and bladder tumor growth. We report here that global deletion of SR$\mathrm{B} 1$ protects mice against $\mathrm{B} 16 \mathrm{~F} 10$ melanoma tumor growth and myeloid-specific deletion of either ABCA1 or ABCG1, or the combined myeloid deletion of both $\mathrm{ABCA} 1$ and ABCG1 in somatic cells, protects mice against B16F10 melanoma tumor growth, with comparable results for ABCA1 in a syngeneic MB49 murine bladder cancer model. Our studies newly identify a potential melanoma tumor-permissive role for SR-B1 and myeloid ABCA1 in non-tumor somatic cells in tumor bearing hosts.

\section{RESULTS}

\section{Global deletion of scavenger receptor class B, type 1 is protective against melanoma}

To examine the impact of somatic cell SR-B1 on melanoma tumor growth, wild-type C57BL/6J mice $\left(\mathrm{Scarbl}^{+/+}\right)$, or mice either heterozygous $\left(\mathrm{Scarbl}^{+/}\right)$or homozygous $\left(S c a r b 1^{-/}\right)$for deletion of $S c a r b 1$, were inoculated subcutaneously with B16F10 melanoma cells $\left(10^{5}\right.$ cells/flank $)$ and tumor growth was monitored over time by caliper measurements. If SR-B1 plays a role in the anti-tumor effect observed with apoA-I or HDL (1), we would anticipate enhanced tumor growth in the absence of SR-B1. In contrast, however, tumor growth in $S c a r b 1^{+/}$mice was significantly $(\mathrm{p}<0.05)$ inhibited by approximately 3 -fold relative to WT mice, with no 
significant further reduction in growth of tumor observed in Scarb1 $^{-/}$mice (Figure 1A). Consistent with previous observations [25], significant increases in plasma total cholesterol (analysis of variance (ANOVA) between

\section{A) B16F10 melanoma}

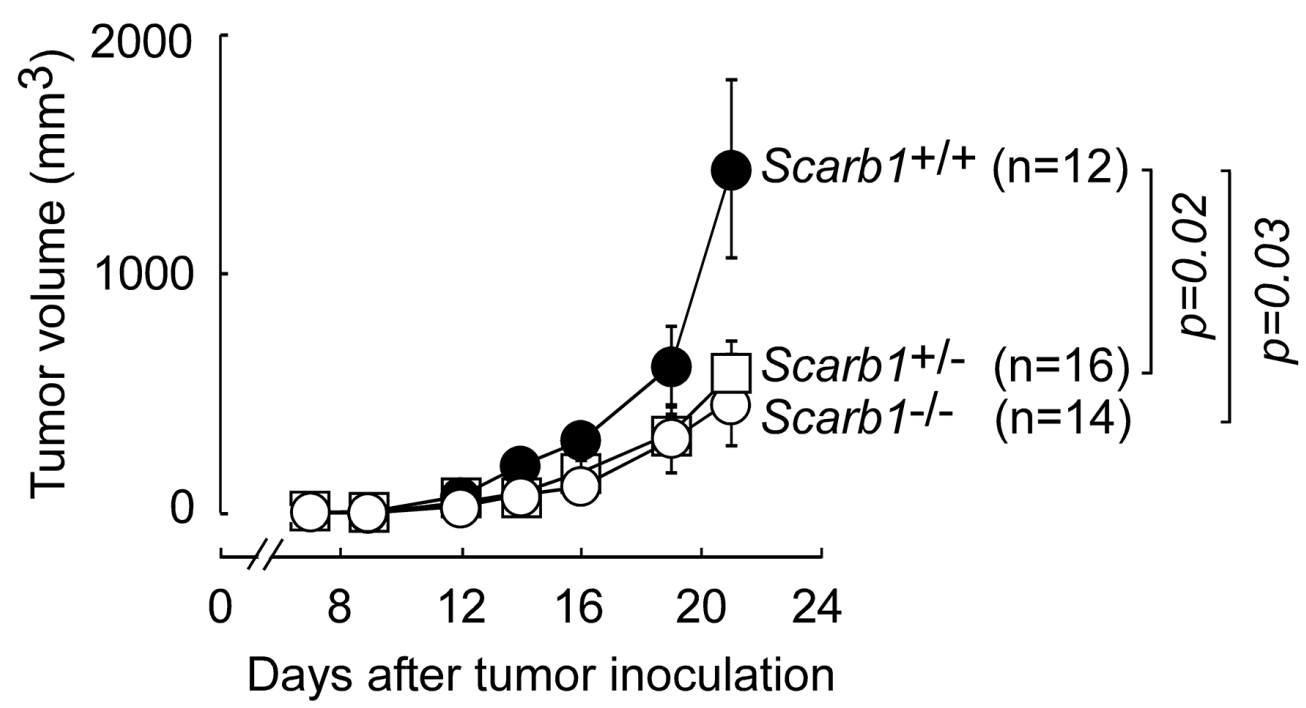

B) Tumor-bearing mice

$p<0.01$ (ANOVA)

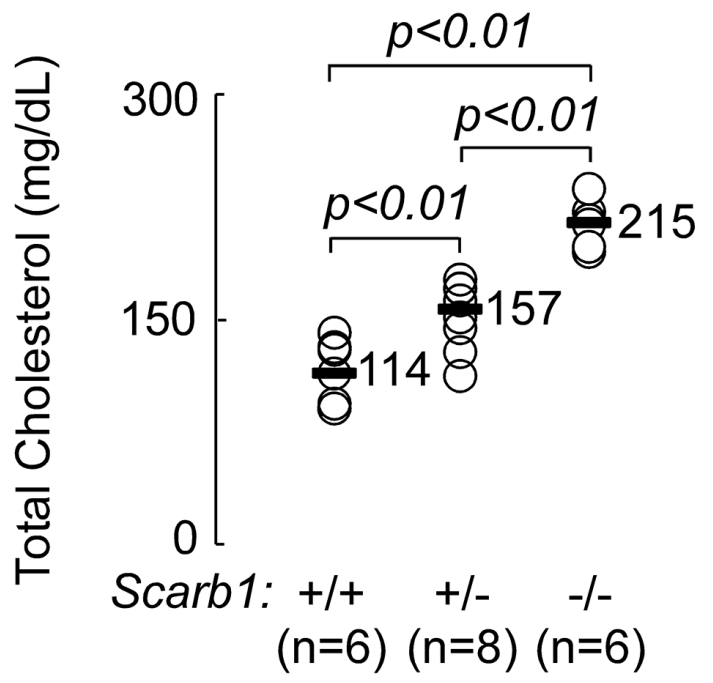

$p<0.01$ (ANOVA)

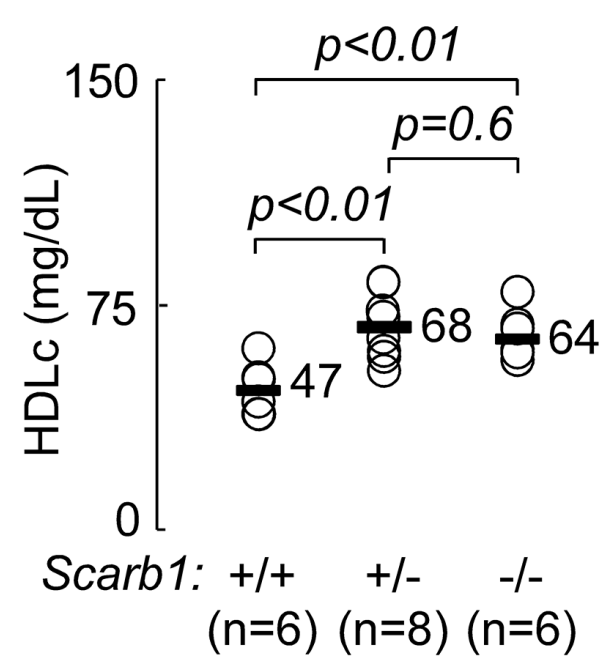

Figure 1: Global deletion of scavenger receptor B1 (SR-B1) is protective against melanoma. C57BL/6 animals wild type $\left(\operatorname{Scarbl}^{+/+}\right)$, hetero- $\left(\operatorname{Scarb1}^{+/}\right)$or homozygously $\left(S c a r b 1^{-/}\right)$deleted at the locus for scavenger receptor type B, class 1 gene $(S c a r b 1)$ were inoculated subcutaneously $\left(10^{5}\right.$ cells/flank) with B16F10 melanoma cells on day 0. (A) Tumor development was monitored by caliper measurements and tumor volume was calculated as described in Materials and Methods. $\mathrm{n}=$ number of inoculation sites, 2 sites/animal. Results shown are the mean \pm SEM of a single experiment and are representative of repeat experiments. (B) Tumor bearing animals were sacrificed 21-days post tumor inoculation and plasma lipid distribution was determined as described in Materials and Methods. The median for each group is indicated. $p$ values between two groups were determined by Student's $t$-test. Analysis of variance (ANOVA) across all three groups is shown above each graph. 
the groups $\mathrm{p}<0.01)$ were observed in mice with genetic deletion of $S c a r b 1$ relative to WT mice (Figure 1B; 38\% increase, WT vs $\mathrm{Scarb1}^{+/}$, and $89 \%$ increase, WT vs $\left.S c a r b 1^{--}\right)$. Further, lipoprotein subfractionation revealed

A) B16F10 melanoma

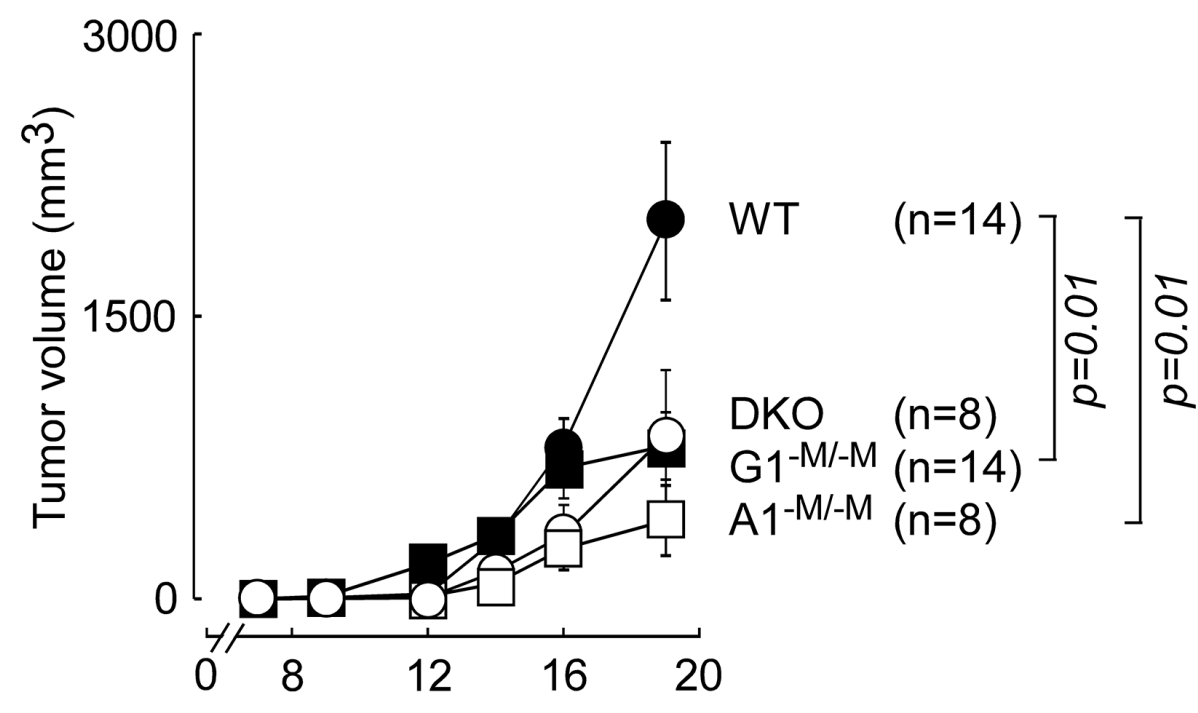

Days after tumor inoculation

B) Tumor-bearing mice

$p<0.01$ (ANOVA)

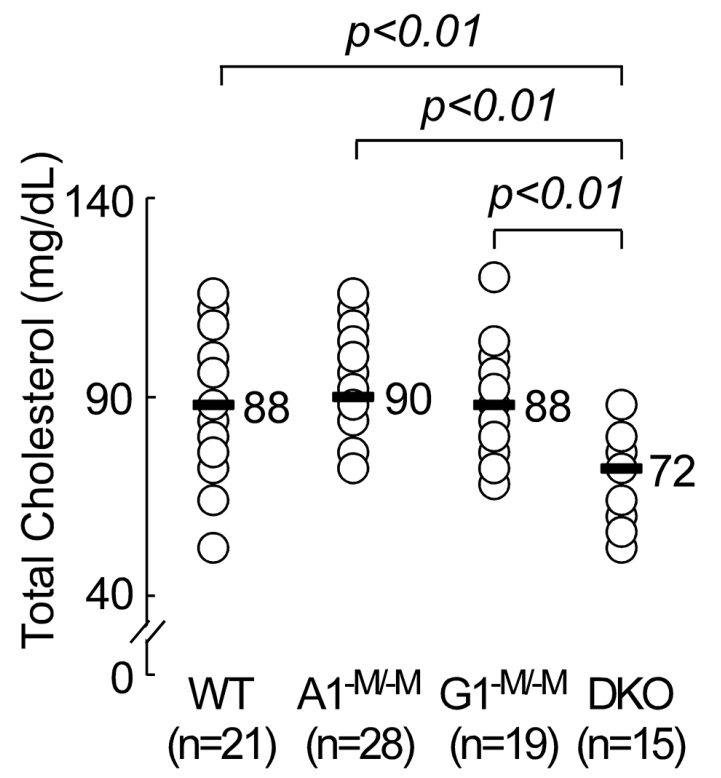

$p=0.01$ (ANOVA)

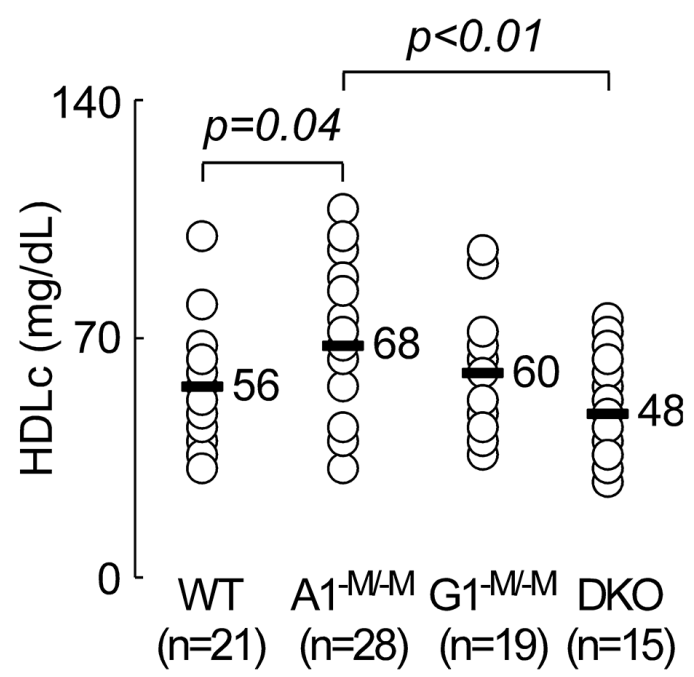

Figure 2: Mice with myeloid-specific deletion of ATP-binding cassette transporter ABCA1 are protected against melanoma- additive deletion in ABCG1 did not provide further protection. C57BL/6 mice with wild type (WT; LysM-Cre $\left.A b c a 1^{+/+} A b c g 1^{+/+}\right)$, myeloid deletion of $A b c a l\left(\mathrm{~A} 1^{-\mathrm{M} /-\mathrm{M}}\right), A b c g 1\left(\mathrm{G} 1^{-\mathrm{M} / \mathrm{M}}\right)$, or $A b c a 1$ and $A b c g 1$ (DKO) were inoculated with B16F10 tumor cells ( $10^{5}$ cells/flank) on day 0 . (A) Tumor development was monitored by caliper measurements and tumor volume calculated as described in Materials and Methods. $\mathrm{n}=$ number of inoculation sites, 2 sites/animal. Results shown are the mean \pm SEM. (B) Tumor bearing animals (B16F10 and MB49) were analyzed for plasma lipid distribution as described in Materials and Methods. The median for each group is indicated. $p$ values between two groups were determined by Student's $t$-test. Analysis of variance (ANOVA) across all four groups is shown above each graph. 
a $44 \%$ increase in HDLc in $S c a r b 1^{+/-}$relative to WT, but no further increase in HDLc in Scarb1 ${ }^{-/}$(Figure 1B right panel). Interestingly, we observed a noticeable increase in LDLc in SR-B1 null mice $(42 \pm 16,73 \pm 13$, and $128 \pm 7$

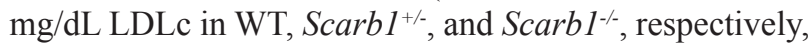
data not shown). This suggests that in our tumor-bearing animals the increased total plasma cholesterol in SR-B1 null mice relative to $S c a r b 1^{+-}$(Figure 1B), may have primarily partitioned to LDL instead of HDL particles. The observation in the present study that changes in HDLc are inversely correlated with tumor volume is consistent with our previous finding that higher HDL levels are associated with enhanced protection against melanoma [1]. Collectively, these results suggest that the anti-tumor activity of elevated HDL levels are independent of host SR-B1 and that loss of this receptor in host somatic cells hinders syngeneic transplanted melanoma tumor development.

\section{Mice with myeloid-specific deletion of ABCA1 are protected against melanoma and bladder cancer while additive deletion of ABCG1 does not provide further tumor inhibition}

We previously reported that myeloid cells constitute a major immune cell infiltrate in B16F10 melanoma and that TAMs from apoA-I transgenic mice, which were protected from tumor development, had an M1- proinflammatory-like phenotype relative to TAMs from apoA-I knock-out mice [1]. Since SR-B1 does not appear to be involved in mediating this protective effect (Figure 1A), we hypothesized that myeloid cells deficient in either ABCA1, ABCG1 or both, which in multiple studies have previously been noted to have an inflammatory gene signature [2, 16, 26-28], might be protective in a B16F10 melanoma tumor model. To examine this possibility we used mice with myeloid-specific deletion of Abcal (A1M/-M [28]), Abcgl (G1-M/-M), or both Abcal and Abcgl (double knock-out (DKO) [2]). These animals express the Cre recombinase (LysM-Cre) in myeloid cells only, thus deleting loxP-floxed Abcal and Abcgl in a tissue-specific manner. In this study, the WT control mice also express the Cre recombinase in myeloid cells (LysM-Cre) but lack loxP sites in Abcal and Abcgl genes. Animals were inoculated with B16F10 melanoma cells ( $10^{5}$ tumor cells/ flank) and tumor development over time was quantified. Relative to WT mice, tumor growth was inhibited (on day 19 post inoculation) by 4.8-, 2.5-, and 2.3-fold in A1 ${ }^{-\mathrm{M} / \mathrm{-M}}$, $\mathrm{G} 1^{-\mathrm{M} / \mathrm{M}}$, and $\mathrm{DKO}$, respectively (Figure 2A). Importantly, loss of myeloid Abcal alone was sufficient to significantly inhibit tumor development $(\mathrm{p}=0.01)$, and additional deletion of $A b c g 1$ in the same immune cells did not lead to enhanced suppression of tumor growth (Figure 2A). Furthermore, the anti-tumor effects observed were noted in relatively young (3-4 months) animals on regular chow diet and did not require either aged mice (6-7 months old) or a high fat "western"-type diet, as was recently reported as a requirement for tumor suppressive phenotype in Abcg1 $1^{-/}$mice [24]. ANOVA analysis of plasma lipid profiles across the groups showed significant differences in total cholesterol and HDLc $(\mathrm{p}<0.01)$. Moreover, while $\mathrm{A} 1^{-\mathrm{M} / \mathrm{M}}$ or $\mathrm{G} 1^{-\mathrm{M} / \mathrm{M}}$ mice showed no difference in total cholesterol level relative to WT, the myeloid specific DKO animals exhibited a modest (18-20\%) but statistically significant decrease in plasma total cholesterol levels $(\mathrm{p}<0.01)$ relative to $\mathrm{WT}$ and each of the single receptor knock-out mice (Figure 2B, left panel). The reduction in circulating cholesterol in the DKO mice did not translate into a significant difference in HDLc between WT and DKO (Figure 2B, right panel). Hepatic (not myeloid) ABCA1 has been reported to be the major determinant of plasma HDLc levels [29]. Therefore, the modest but statistically significant increase in HDLc in the $\mathrm{A} 1^{-\mathrm{M} / \mathrm{M}}$ group of mice was unexpected and may contribute to the tumor protection observed in this group, though a similar increase in HDLc was not observed in $\mathrm{G} 1^{-\mathrm{M} / \mathrm{M}}$ or DKO (Figure 2B, right panel).

We next examined whether the tumor inhibition observed in animals with myeloid ablation of ABCA1 was specific to B16F10 melanoma. Animals (6-7 months old) were inoculated subcutaneously $\left(10^{5}\right.$ cells/flank $)$ with an alternative syngeneic tumor model, MB49 bladder carcinoma cells, and tumor progression over time was subsequently followed by caliper measurements. After 19-days there was a 5.7-fold inhibition in tumor volume in the $\mathrm{A} 1^{-\mathrm{M} / \mathrm{M}}$ animals relative to WT controls $(\mathrm{p}=0.02)$, and a similar trend toward inhibition in DKO animals, although the numbers did not reach statistical significance (Figure 3). In contrast to B16F10 melanoma, we did not observe tumor protection in younger $\mathrm{A} 1^{-\mathrm{M} / \mathrm{M}}$ mice (data not shown). These results suggest that the therapeutic targeting of myeloid ABCA1 may be effective against a wide spectrum of cancers.

\section{Myeloid-specific deletion of ABCA1 and ABCG1 inhibits tumor bed accumulation of MDSCs}

Tumor proliferation is largely influenced by infiltrating immune cells, which are recruited and subverted by the tumor microenvironment to promote tumor growth and metastasis. Since myeloid cells constitute the majority of infiltrating immune cells in B16F10 melanoma [1], we sought to examine if myeloidspecific transporter deletions influenced the composition of infiltrating leukocytes within the tumor bed. After inoculation of B16F10 cells, tumors were excised (day 19) and processed for FACs analyses, as described in Materials and Methods. Host immune cells were differentiated from tumor cells by surface staining for the hematopoietic leukocyte common antigen, CD45 [30]. In Figure 4A and $4 \mathrm{~B}$, tumor volume and weight are shown for each group of mice. There was a 10-, 2.3-, and 4.7-fold inhibition in 
median tumor volume on the day of sacrifice in $\mathrm{A} 1^{-\mathrm{M} / \mathrm{M}}$, $\mathrm{G} 1^{-\mathrm{M} / \mathrm{M}}$ and myeloid-specific DKO mice, respectively relative to control WT mice, with only $\mathrm{A} 1^{-\mathrm{M} / \mathrm{M}}$ and $\mathrm{G} 1^{-\mathrm{M} / \mathrm{M}}$, but not myeloid-specific DKO mice, showing significant differences $(p=0.02, p=0.01$, and $p=0.08$, respectively). The remaining panels in Figures 4 and 5 include contour diagrams to the left to illustrate gating used during flow cytometry, and the panels to the right represent scatter plots quantifying the number of tumor-infiltrating cells for the indicated surface antigens per gram tumor tissue in all four groups. The number of infiltrating CD $45^{+}$cells $/ g$ tumor was reduced by 2.8-, 1.6-, and 14-fold in A1 $1^{-\mathrm{M} / \mathrm{-M}}$, $\mathrm{G} 1^{-\mathrm{M} / \mathrm{M}}$ and DKO animals relative to WT $(\mathrm{p}=0.01, \mathrm{p}<0.01$, and $\mathrm{p}<0.01$, respectively, Figure 4C). Myeloid cells $\left(\mathrm{CD} 11 \mathrm{~b}^{+}\right)$constituted nearly $50 \%$ or greater of these tumor infiltrating leukocytes (Figure 4D). Although there was a similar trend (decrease in receptor knock-out mice relative to WT) in levels of $\mathrm{CD} 1 \mathrm{~b}^{+} \mathrm{F} 4 / 80^{+}$macrophages (ANOVA $\mathrm{p}=0.15$ ), the decrease was only statistically significant between WT and DKO (6-fold decrease, $\mathrm{p}<0.01$, data not shown).

In mice, MDSCs are broadly characterized as $\mathrm{CD}_{11} \mathrm{~b}^{+} \mathrm{GR} 1^{+}$, where the myeloid differentiation antigen GR1 consists of two epitopes, Ly-6G and Ly-6C [23]. There were fewer MDSCs in tumors from all receptor knock out groups relative to WT controls (3.7-, 1.8, and 11-fold decrease in $\mathrm{A} 1^{-\mathrm{M} / \mathrm{M}}, \mathrm{G} 1^{-\mathrm{M} / \mathrm{M}}$, and $\mathrm{DKO}$, respectively; $\mathrm{p}=0.01, \mathrm{p}=0.08$ and $\mathrm{p}<0.01$, respectively, Figure 5A). Importantly, myeloid ablation of ABCA1 resulted in an almost 11-fold decrease in granulocytic MDSCs, Ly-6G+Ly-6C ${ }^{\text {Lo }}$ (median= 0.64 and 0.06 X $10^{6}$ cells/gram tumor tissue in $\mathrm{WT}$ and $\mathrm{A} 1^{-\mathrm{M} / \mathrm{-M}}$, respectively, $\mathrm{p}=0.04$, Figure $5 \mathrm{~B}$, top plot). There was no statistically significant difference between $\mathrm{G} 1^{-\mathrm{M} / \mathrm{M}}$ and $\mathrm{WT}(\mathrm{p}=0.18$, Figure 5B, top plot) but a significant 7-fold decrease in $\mathrm{Ly}-6 \mathrm{G}^{+} \mathrm{Ly}-6 \mathrm{C}^{\mathrm{Lo}}$ cells in DKO (median= 0.64 and $0.09 \times 10^{6}$ cells/gram tumor tissue in WT and DKO, respectively, $\mathrm{p}<0.05$, Figure $5 \mathrm{~B}$, top plot). In contrast,

\section{MB49 murine bladder cancer}

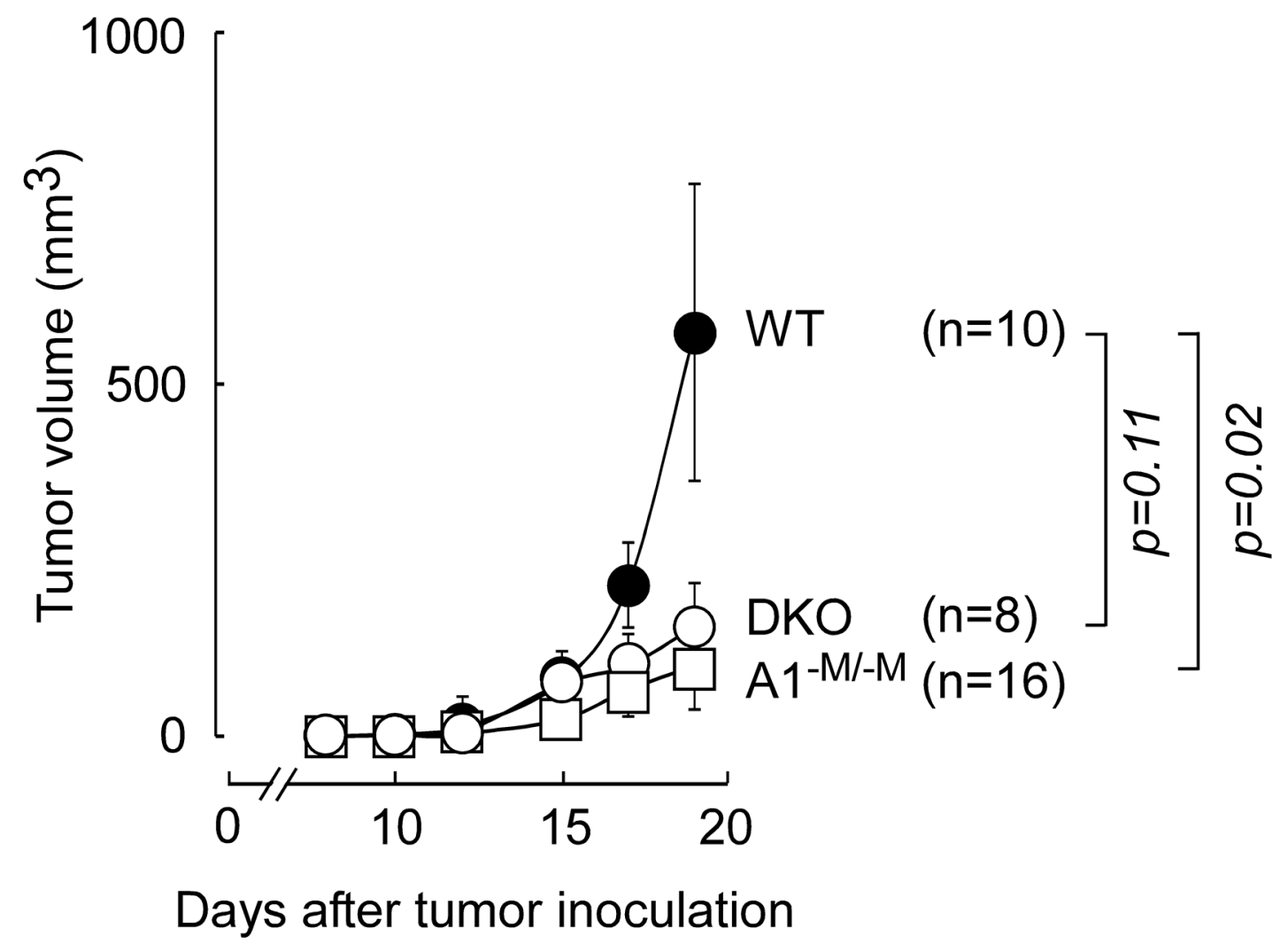

Figure 3: Mice with myeloid-specific deletion of ABCA1, are protected against MB49 bladder cancer on normal chow diet. C57BL/6 mice with wild type (WT; LysM-Cre Abca1 ${ }^{+/+} A b c g 1^{+/+}$), myeloid deletion of $A b c a 1$ (A1 ${ }^{-\mathrm{M} / \mathrm{M}}$ ) or $A b c a 1$ and $A b c g 1$ (DKO) were inoculated with $10^{5} \mathrm{MB} 49$ cells/flank on day 0 . Tumor development was monitored by caliper measurements and tumor volume calculated as described in Materials and Methods. $\mathrm{n}=$ number of inoculation sites, 2 sites/animal. Results shown are the mean tumor volume \pm SEM. $p$ values between two groups were determined by Student's $t$-test. 
myeloid ablation of ABCG1 resulted in a statistically significant decrease (2.7-fold) in numbers of monocytic
MDSCs, Ly-6G ${ }^{\text {neg }} \mathrm{Ly}-6 \mathrm{C}^{\mathrm{Hi}}$ (median=0.9 and $0.33 \mathrm{X} 10^{6}$ cells/gram tumor tissue in $\mathrm{WT}$ and $\mathrm{G} 1^{-\mathrm{M} / \mathrm{M}}$, respectively,

\section{B16F10 melanoma}

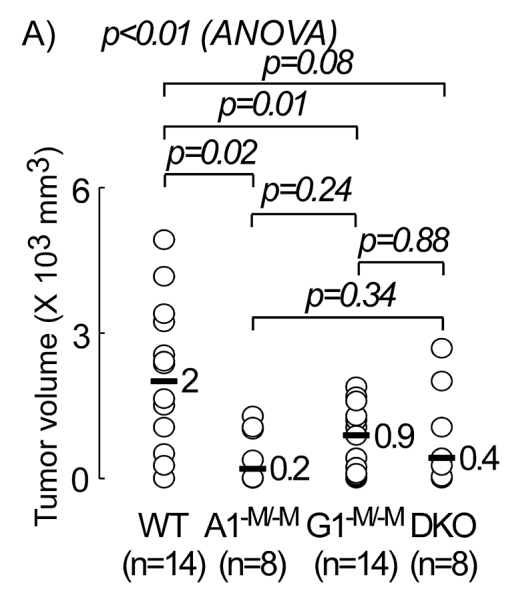

C)

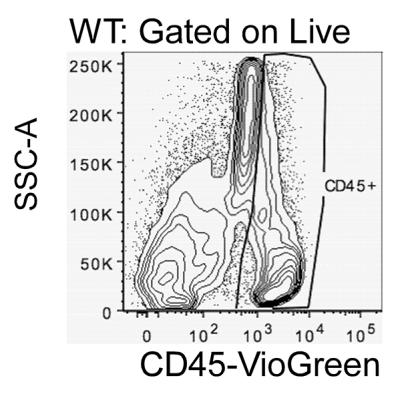

D)

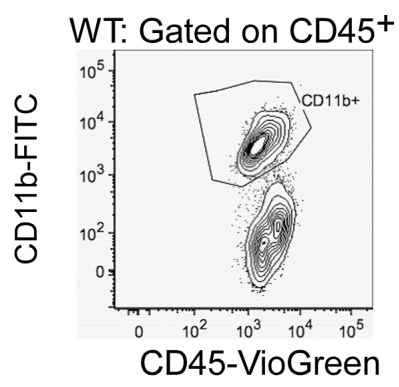

B) $\quad p=0.05$ (ANOVA)
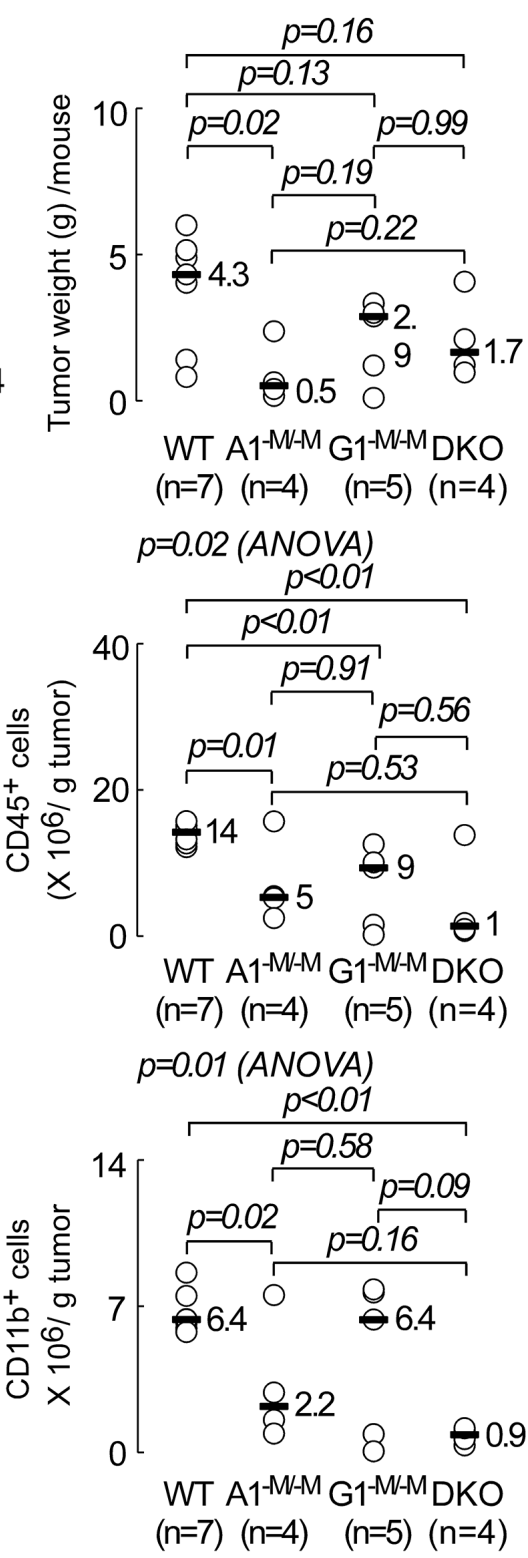

Figure 4: Myeloid-specific deletion of ABCA1 and ABCG1 transporters inhibits accumulation of leukocytes in tumor bed. C57BL/6 mice with wild type (WT; $L y s M-C r e ~ A b c a 1^{+++} A b c g 1^{+++}$), myeloid deletion of $A b c a l\left(\mathrm{~A} 1^{-\mathrm{M} /-\mathrm{M}}\right), A b c g 1$ (G1 $1^{-\mathrm{M}-\mathrm{M}}$ ) or $A b c a 1$ and Abcgl (DKO) were inoculated with B16F10 tumor cells ( $10^{5}$ cells/flank) and sacrificed 19-days later. (A) Individual tumor volumes (2 per animal) as determined by caliper measurement (see Materials and Methods) on day of sacrifice, day 19. (B) Pooled tumor weight per animal which were processed for FACs analyses. (C) Number of tumor infiltrating leukocytes (CD45 ) per gram tumor tissue. Cells were gated on live. Resected tumors (two per animal) from individual mice ( $\mathrm{n}=7, \mathrm{WT} ; \mathrm{n}=4, \mathrm{A1} 1^{-\mathrm{M} / \mathrm{M}}$ and $\mathrm{DKO}$, and $\mathrm{n}=5$, $\mathrm{G1} 1^{-\mathrm{M} / \mathrm{M}}$ ) were digested to obtain single cells for surface antigen staining and analysis by flow cytometry, as described in Materials and Methods. (D) Number of tumor infiltrating CD11b cells per gram tumor tissue. Cells were gated on live and $\mathrm{CD} 45^{+}$. Representative FACs images to the left are WT Control and are gated on live (C), and live/ $\mathrm{CD}^{+} 5^{+}$(D). $p$ values between two groups were determined by Student's $t$-test. Analysis of variance (ANOVA) across all four groups is shown above each graph. 
$\mathrm{p}<0.01$, Figure $5 \mathrm{~B}$, lower plot). There was even further decrease (15-fold) in the monocytic MDSC subset in
DKO (median $=0.9$ and $0.06 \times 10^{6}$ cells/gram tumor tissue in WT and DKO, respectively, $\mathrm{p}<0.01$, Figure

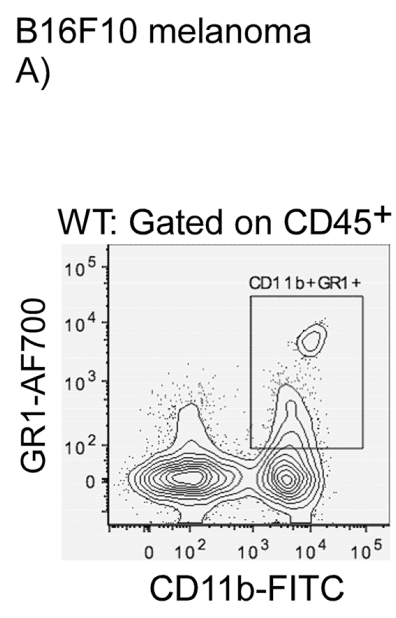

B)

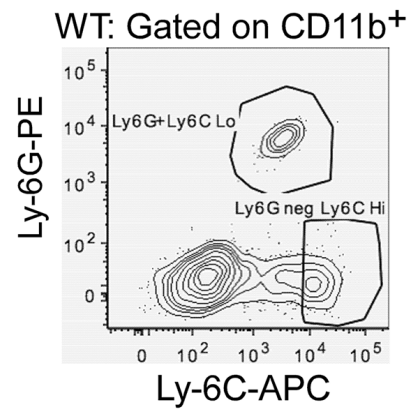

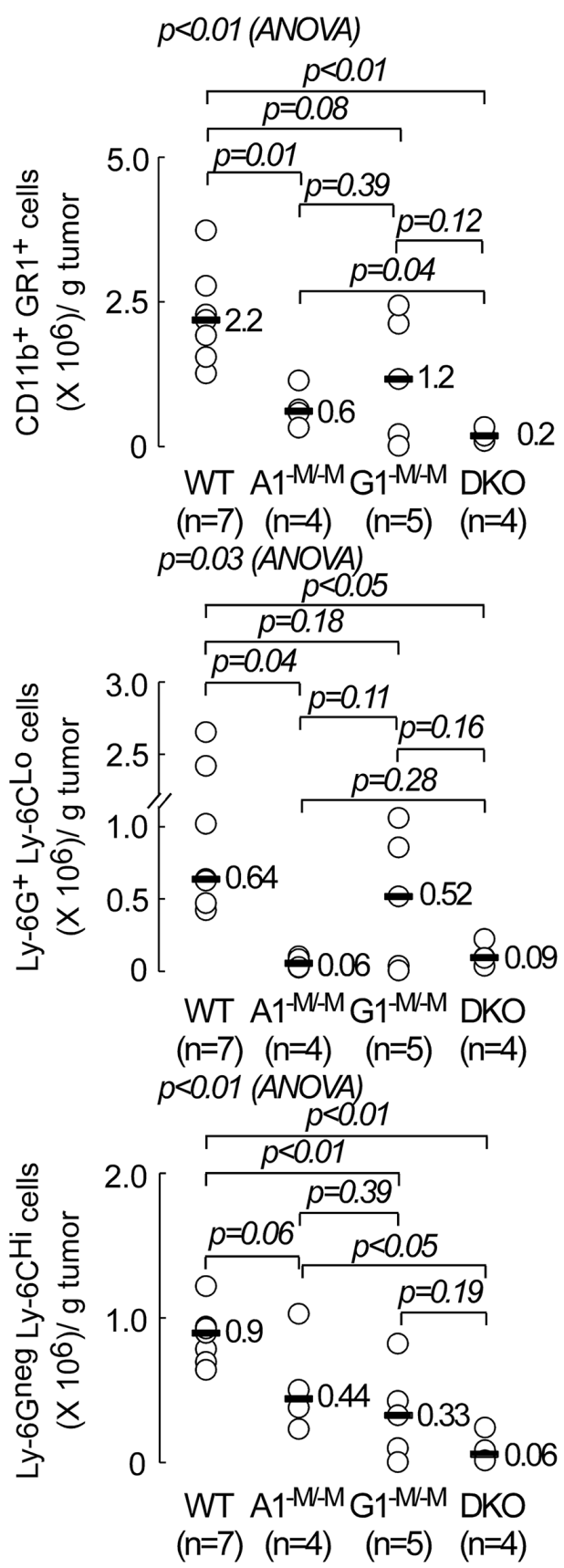

Figure 5: Myeloid-specific deletion of ABCA1 and ABCG1 transporters inhibits accumulation of myeloid derived suppressor cells (MDSCs) in tumor bed. C57BL/6 mice with wild type (WT; $\mathrm{LysM}$-Cre Abcal $\mathrm{I}^{+/+} \mathrm{Abcg} \mathrm{I}^{+/+}$), myeloid deletion of $A b c a l\left(\mathrm{~A} 1^{-\mathrm{M} / \mathrm{M}}\right), A b c g 1\left(\mathrm{G} 1^{-\mathrm{M}-\mathrm{M}}\right)$ or $A b c a l$ and $A b c g l(\mathrm{DKO})$ were inoculated with B16F10 tumor cells (10 $\mathrm{s}$ cells/flank) and sacrificed 19-days later. Resected tumors (two per animal) from individual mice ( $\mathrm{n}=7, \mathrm{WT} ; \mathrm{n}=4, \mathrm{~A} 1^{-\mathrm{M} / \mathrm{M}}$ and $\mathrm{DKO}$, and $\mathrm{n}=5$, $\mathrm{G} 1^{-\mathrm{M} / \mathrm{M}}$ ) were digested to obtain single cells for surface antigen staining and analysis by flow cytometry, as described in Materials and Methods. (A) Number of

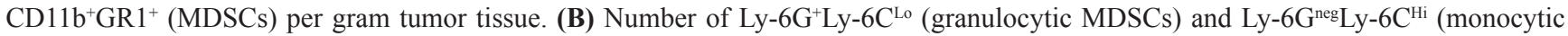
MDSCs) per gram tumor. Representative FACs images to the left are WT Control and are gated on live/ $\mathrm{CD}^{+} 5^{+}$(A), and on live/ $\mathrm{CD}^{+} 5^{+}$ $\mathrm{CD}_{11 \mathrm{~b}^{+}}$(B). $p$ values between two groups were determined by Student's $t$-test. Analysis of variance (ANOVA) across all four groups is shown above each graph. 
B16F10 melanoma: Spleen
A) Splenic CD11 $\mathrm{b}^{+}$
$p<0.01$ (ANOVA)
B) Splenic CD11b+ GR1+

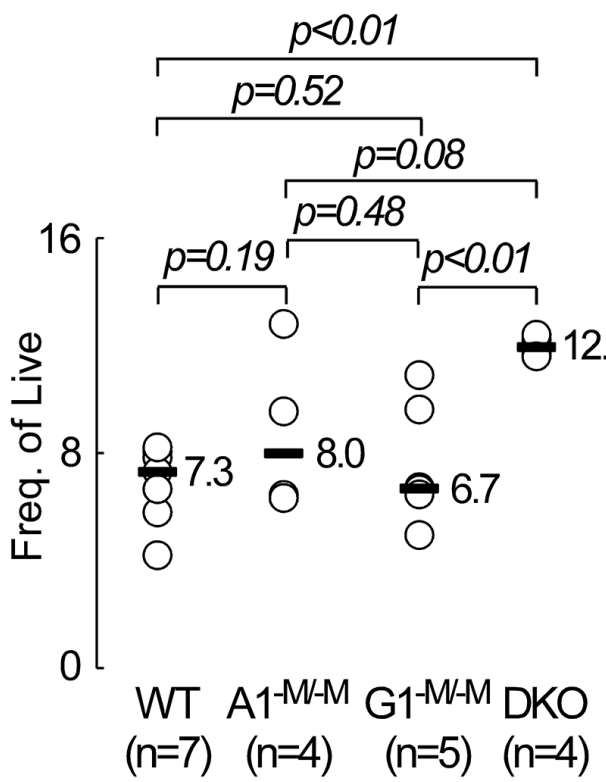 $p<0.01$ (ANOVA)

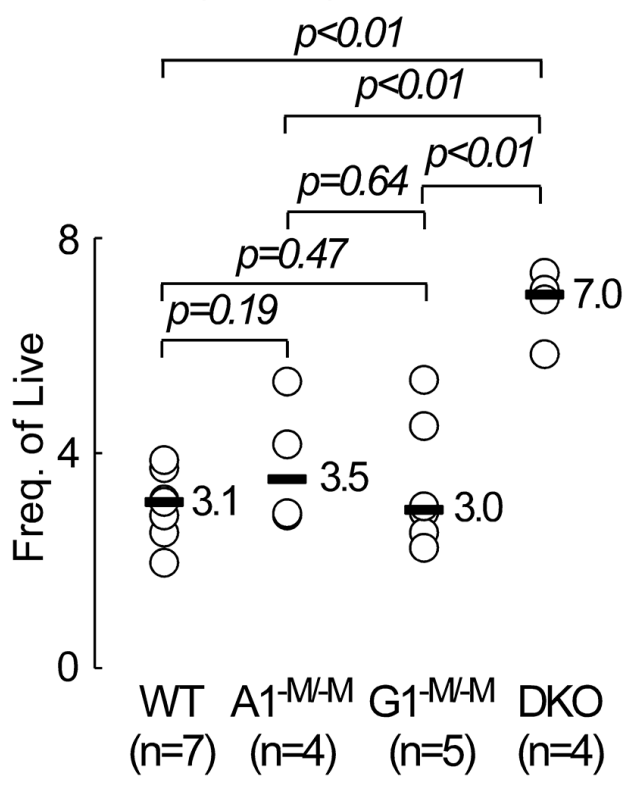

C) Splenic Ly-6Gneg Ly-6CHi $p<0.01$ (ANOVA)

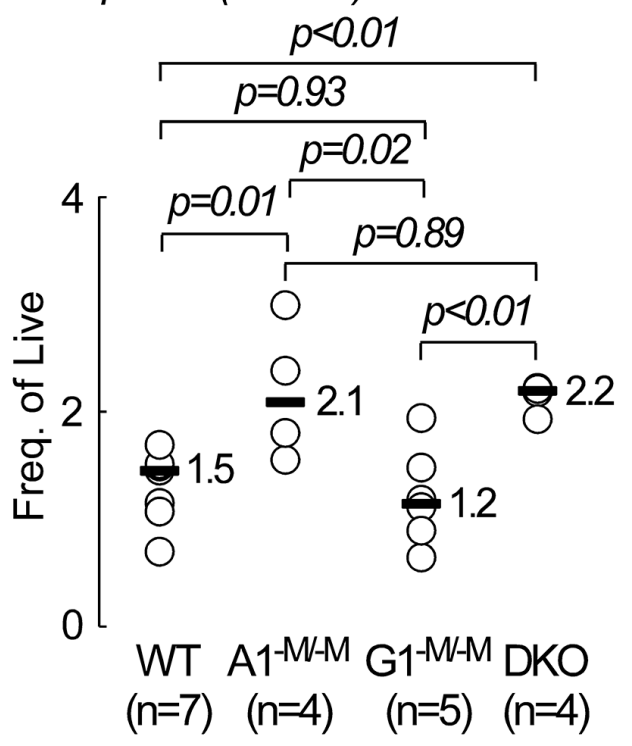

D) Splenic Ly-6G+ Ly-6CLo $p<0.01$ (ANOVA)

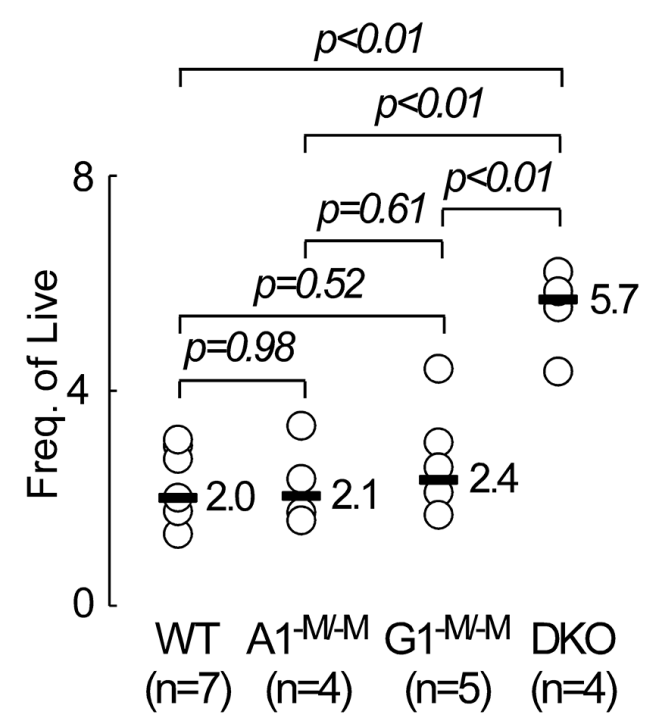

Figure 6: Animals with myeloid-specific deletion of both ABCA1 and ABCG1 transporters (DKO) exhibit higher frequencies of splenic $\mathbf{C D}_{11} \mathrm{~b}^{+}$, CD11b ${ }^{+} \mathbf{G R 1}{ }^{+}$, monocytic and granulocytic MDSCs. C57BL/6 mice with wild type (WT;

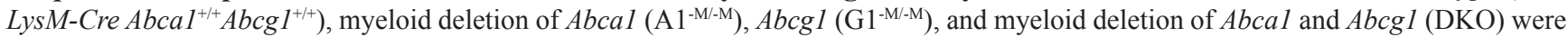
inoculated with B16F10 tumor cells ( $10^{5}$ cells/flank) and sacrificed 19-days later. Individual spleens were processed for FACs analysis as described in Materials and Methods. Cells were gated on live for analysis. (A) Frequency of splenic CD11b ${ }^{+}$cells. (B) Frequency of

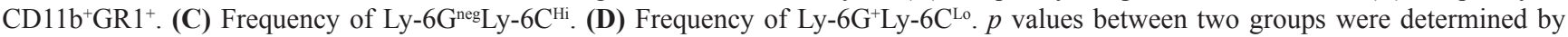
Student's $t$-test. Analysis of variance (ANOVA) across all four groups is shown above each graph. 
Table 1: Mice with myeloid specific deletion of ATP-binding cassette transporter ABCA1 exhibit reduced circulating monocytes and neutrophils.

\begin{tabular}{|c|c|c|c|c|c|c|c|c|c|c|}
\hline Cells $/ \mu \mathrm{l}$ & WT $(n=12)$ & $\begin{array}{l}A 1^{-M /-M} \\
(n=11)\end{array}$ & $\begin{array}{l}G 1^{-M /-M} \\
(n=10)\end{array}$ & $\operatorname{DKO}(n=6)$ & $\begin{array}{c}\text { A1 } 1^{-\mathrm{M} / \mathrm{M}} \\
\text { vs WT } \\
p \text {-value }\end{array}$ & $\begin{array}{c}\text { G1 }{ }^{-\mathrm{M} /-\mathrm{M}} \\
\text { vs WT } \\
p \text {-value }\end{array}$ & $\begin{array}{c}\text { DKO } \\
\text { vs WT } \\
p \text {-value }\end{array}$ & $\begin{array}{c}\mathrm{A1}^{-} \\
\mathrm{M} /-\mathrm{M} \\
\mathrm{GS} \\
\mathbf{G} 1^{-\mathrm{M} /-\mathrm{M}} \\
p \text {-value }\end{array}$ & $\begin{array}{c}\mathrm{A1}^{-\mathrm{M} / \mathrm{M}} \\
\text { vs DKO } \\
p \text {-value }\end{array}$ & $\begin{array}{c}\mathrm{G1}^{-\mathrm{M} / \mathrm{M}} \\
\text { vs DKO } \\
p \text {-value }\end{array}$ \\
\hline $\begin{array}{l}\text { WBC } \\
\left(10^{3}\right)\end{array}$ & $3.93 \pm 0.78$ & $2.22 \pm 0.31$ & $3.35 \pm 0.61$ & $3.63 \pm 0.49$ & 0.063 & 0.575 & 0.798 & 0.106 & 0.023 & 0.757 \\
\hline $\begin{array}{l}\text { Neut } \\
\left(10^{3}\right)\end{array}$ & $1.03 \pm 0.23$ & $0.49 \pm 0.1$ & $1.38 \pm 0.43$ & $1.47 \pm 0.45$ & 0.046 & 0.460 & 0.338 & 0.050 & 0.014 & 0.891 \\
\hline $\begin{array}{l}\text { Lymph } \\
\left(10^{3}\right)\end{array}$ & $2.48 \pm 0.54$ & $1.57 \pm 0.23$ & $1.65 \pm 0.21$ & $1.88 \pm 0.14$ & 0.153 & 0.202 & 0.457 & 0.809 & 0.373 & 0.453 \\
\hline $\begin{array}{l}\text { Mono } \\
\left(10^{3}\right)\end{array}$ & $0.32 \pm 0.09$ & $0.08 \pm 0.01$ & $0.25 \pm 0.05$ & $0.17 \pm 0.03$ & 0.026 & 0.581 & 0.285 & 0.005 & 0.018 & 0.281 \\
\hline $\begin{array}{l}\text { Eos } \\
\left(10^{3}\right)\end{array}$ & $0.02 \pm 0.00$ & $0.02 \pm 0.00$ & $0.02 \pm 0.00$ & $0.04 \pm 0.00$ & 0.938 & 0.470 & 0.136 & 0.532 & 0.122 & 0.001 \\
\hline $\begin{array}{l}\text { Baso } \\
\left(10^{3}\right)\end{array}$ & $0.06 \pm 0.02$ & $0.05 \pm 0.03$ & $0.02 \pm 0.01$ & $0.04 \pm 0.01$ & 0.877 & 0.100 & 0.457 & 0.339 & 0.708 & 0.217 \\
\hline $\begin{array}{l}\text { RBC } \\
\left(10^{6}\right)\end{array}$ & $3.79 \pm 0.53$ & $3.96 \pm 0.82$ & $2.93 \pm 0.55$ & $5.41 \pm 0.79$ & 0.860 & 0.270 & 0.099 & 0.315 & 0.265 & 0.018 \\
\hline $\begin{array}{l}\text { PLT } \\
\left(10^{4}\right)\end{array}$ & $53.53 \pm 7.40$ & $50.90 \pm 11.33$ & $\begin{array}{c}45.17 \pm \\
8.76\end{array}$ & $69.45 \pm 10.46$ & 0.846 & 0.471 & 0.232 & 0.697 & 0.301 & 0.103 \\
\hline $\mathrm{HGB}(\mathrm{g} / \mathrm{dL})$ & $4.64 \pm 0.91$ & $5.97 \pm 1.26$ & $4.36 \pm 0.99$ & $7.92 \pm 1.14$ & 0.395 & 0.836 & 0.046 & 0.334 & 0.326 & 0.039 \\
\hline $\begin{array}{l}\text { HCT } \\
(\%)\end{array}$ & $19.46 \pm 2.42$ & $19.20 \pm 3.89$ & $\begin{array}{c}16.37 \pm \\
2.86\end{array}$ & $26.10 \pm 3.36$ & 0.955 & 0.417 & 0.131 & 0.572 & 0.258 & 0.050 \\
\hline
\end{tabular}

Results from complete blood counts and differentials from tumor-bearing (B16F10 melanoma) mice on chow diet recovered at time of sacrifice by cardiac puncture, as described in Materials and Methods. Number of mice in each group is indicated (n). Results shown are the mean \pm SEM. $p$-values were determined by Student's $t$-test for the indicated comparison.

5B, lower plot). There was no statistically significant difference in monocytic MDSCs between $\mathrm{A} 1^{-\mathrm{M} / \mathrm{M}}$ and WT $(p=0.06$, Figure 5B, lower plot). These results suggest that myeloid ABCA1 may be important in the accumulation of granulocytic MDSCs (Ly-6G+Ly-6C $\left.{ }^{\mathrm{Lo}}\right)$ whereas myeloid ABCG1 may govern the frequency of monocytic MDSCs (Ly-6G $\left.{ }^{\text {neg }} \mathrm{Ly}-6 \mathrm{C}^{\mathrm{Hi}}\right)$ in the tumor microenvironment. The lower numbers of MDSCs in animals with myeloid ablation of ABCA1 and ABCG1 was specific to the tumor compartment as these cells were not decreased in the spleen of receptor knock-out mice relative to WT animals (Figure 6B, 6C, and 6D). In contrast to the tumor (Figure 4D), the frequency of

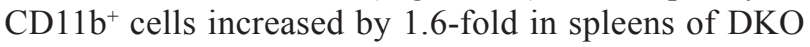
(Figure $6 \mathrm{~A}, \mathrm{p}<0.01$ ). The frequency of Ly-6 $\mathrm{G}^{\text {neg }} \mathrm{Ly}-6 \mathrm{C}^{\mathrm{Hi}}$ cells was increased modestly $(\sim 1.5$-fold $)$ in the spleen of both $\mathrm{A} 1^{-\mathrm{M} / \mathrm{M}}$ and $\mathrm{DKO}$ animals relative to WT (Figure $6 \mathrm{C}, \mathrm{p}=0.01$ and $\mathrm{p}<0.01$, respectively) and that of Ly$6 \mathrm{G}^{+}$Ly-6C ${ }^{\text {Lo }}$ cells was increased only in DKO (2.8-fold relative to WT, Figure $6 \mathrm{D}, \mathrm{p}<0.01$ ).

Analysis of complete blood cell count (CBC) with differentials in naïve (non-tumor bearing) mice revealed no significant differences between $\mathrm{WT}, \mathrm{A} 1^{-\mathrm{M} / \mathrm{M}}$ and DKO except for a mild but statistically significant elevation of monocytes in DKO vs A $1^{-\mathrm{M} / \mathrm{M}}(0.3 \pm 0.04$ vs $0.09 \pm 0.03 \times 10^{3}$ cells $/ \mu 1$ blood in $\mathrm{DKO}$ and $\mathrm{A} 1^{-\mathrm{M} / \mathrm{M}}$, respectively, $\mathrm{p}<0.01$; data not shown). Tumor-bearing (B16F10 melanoma) mice similarly showed no major defects in CBC + differential, except for a statistically significant decrease in numbers of circulating monocytes and neutrophils in $\mathrm{A} 1^{-\mathrm{M} / \mathrm{M}}$ animals relative to WT, G1 $1^{-\mathrm{M} / \mathrm{M}}$ or DKO (Table 1). Further, a trend towards elevated neutrophil count in tumor bearing $\mathrm{G} 1^{-\mathrm{M} / \mathrm{M}}$ and $\mathrm{DKO}$ mice relative to $\mathrm{WT}$ and $\mathrm{A} 1^{-\mathrm{M} / \mathrm{M}}$ mice was observed (Table 1).

\section{DISCUSSION}

Recently, several reports have collectively provided evidence for an immune modulatory role for cholesterol homeostasis pathways in cancer. Notably, large-scale human epidemiological studies have noted an inverse association between circulating HDLc levels and cancer risk [31, 32]. Furthermore, reduced plasma level of 
apoA-I, the predominant protein in HDL, was identified as a biomarker in patients with early-stage ovarian cancer [33-38]. Animal studies have similarly demonstrated that elements of cholesterol homeostasis pathways impact tumor growth and development. For example, apoA-I/ $\mathrm{HDL}$, a lipoprotein involved in cholesterol transport in the circulation, was shown to have anti-tumor activity against both syngeneic and xenogeneic tumor models in mouse $[1,39]$. The ATP binding cassette transporters ABCA1 and ABCG1 promote efflux of excess cholesterol and lipids from peripheral cells to circulating HDL for delivery to the liver and excretion into bile and feces in a physiological process known as reverse cholesterol transport [40, 41]. ABCG1 was recently shown to influence the anti-tumor function of immune cells. Both global and myeloid deletion of Abcgl led to increased tumor immunity in young tumor bearing animals when fed a "western"-type diet, but not a normal chow diet [24]. Interestingly, in aged animals (6-7 months old), the protection associated with Abcgl deficiency was observed in chow-fed animals [24].

In the present study, we extend these observations, and examine the potential role of two distinct apoA-I/ HDL receptors in tumor biology. Global knockout of Scarb1 (SR-B1) in 2-3 month old tumor bearing animals on chow diet led to inhibition of B16F10 tumor development compared to WT animals (Figure 1A) and increased levels of circulating HDLc (Figure 1B). Further, mice with myeloid-specific deletion of Abcal (A1 $1^{-\mathrm{M} / \mathrm{M}}$ ) were protected against tumor development in relatively young (3-4 months old) animals on normal chow diet (Figure 2A). G1 $1^{-\mathrm{M} / \mathrm{M}}$ mice were also protected under these experimental conditions, though not as robustly as $\mathrm{A}^{-\mathrm{M} / \mathrm{M}}$ (Figure 2A). Importantly, $\mathrm{A} 1^{-\mathrm{M} / \mathrm{M}}$ mice were also notable for being resistant to MB49 bladder cancer, suggesting that the protective mechanism triggered by loss of myeloid ABCA1 may be effective against a wide spectrum of tumors (Figure 3A).

We previously showed an innate and adaptive immune-modulatory role for apoA-I levels in melanoma tumor biology [1]. Our present study suggests that the tumor protective effect of increasing apoA-I/HDL levels likely did not function through SR-B1, the primary receptor for HDL particles and a key regulator of total cholesterol levels [42, 43]. Tumor growth was significantly inhibited in animals heterozygous or homozygous for deletion in SR-B1 (Figure 1A). Of interest, a role for SR-B1 in adaptive immunity has previously been suggested since $S c a r b 1^{-1-}$ mice were shown to have increased expression of the proinflammatory cytokines $\mathrm{TNF} \alpha$, and IL-6 and inducible nitric oxide synthetase in circulation, increased frequency of splenic macrophages and impaired lymphocyte homeostasis with activated $\mathrm{T}$ and B cells [44]. Additionally, a further link between HDL and macrophage immune function was suggested by the observation that SR-B1 can mediate bidirectional cholesterol transfer between macrophages and HDL [45, 46]. Of particular note, SR-B1-null mice were reported to have hyperinflammatory macrophages independent of altered cellular or membrane cholesterol content [47]. Whether the observed tumor immunity in our present study is associated with these previously reported phenotypic changes in immune cells of Scarb1-null mice is unknown.

In prior studies, the anti-neoplastic activity of apoA-I and HDL [1], and the tumor protection observed with $A b c g l$ deficiency [24], were suggested to be mediated in part by the myeloid immune cell subset. In particular, macrophages were noted to switch to an M1-like tumorfighting phenotype. Thus, TAMs recovered from tumorbearing apoA-I transgenic mice had a pro-inflammatory M1-like gene signature and peritoneal macrophages from these animals displayed enhanced cytotoxicity towards tumor cells relative to macrophages recovered from tumorbearing apoA-I-null mice [1]. Myeloid-specific loss of ABCA1 and or ABCG1 expression has been shown to impart a pro-inflammatory phenotype to these immune cells $[2,16,24,48,49]$. In the present study, we therefore hypothesized that mice with myeloid-specific Abcal deletion may exhibit resistance to tumor development. Our observations with chow-fed, tumor bearing mice are supportive of this hypothesis, and consistent with our previous observation that pro-inflammatory TAMS inhibit B16F10 tumor development [1].

The recently observed [24] anti-tumor phenotype with $A b c g 1$ deficiency was also noted to be accompanied by enhanced Abcal expression in TAMs, though the potential role of ABCA1 was not examined. In the present study, we show that myeloid loss of Abcal alone was sufficient to confer enhanced tumor immunity in both melanoma (Figure 2) and bladder cancer (Figure 3). We also saw no further inhibition in the rate of tumor development by the additional loss of $A b c g l$ in myeloid cells (Figure 2A; compare DKO to $\mathrm{A} 1^{-\mathrm{M} / \mathrm{M}}$ ). Moreover, unlike the situation reported with ABCG1-myeloid deficiency where the tumor protective effect was observed under conditions of hypercholesterolemia [24], this does not appear to be a prerequisite to elicit tumor protection with ABCA1-myeloid deficiency.

Here, we identified a tumor protective function against B16F10 melanoma and MB49 bladder cancer in mice with myeloid deficiency in ABCA1 (A1 ${ }^{-\mathrm{M} / \mathrm{M}}$ ) or ABCA1 and ABCG1 (DKO). It is possible that this protection may be related to the previously reported proinflammatory anti-tumor phenotype (M1) of TAMS in these animals, a hypothesis that deserves further study [1, 24]. In the present studies, while we saw no statistically significant difference in the numbers of TAMs per gram tumor between different genotypes (data not shown), we did observe a lower frequency of MDSCs in general 
$\left(\mathrm{CD} 11 \mathrm{~b}^{+} \mathrm{GR} 1^{+}\right)$, as well as monocytic $\left(\mathrm{Ly}-6 \mathrm{G}^{\mathrm{neg}} \mathrm{Ly}-6 \mathrm{C}^{\mathrm{Hi}}\right)$ and granulocytic MDSCs $\left(\mathrm{Ly}-6 \mathrm{G}^{+} \mathrm{Ly}-6 \mathrm{C}^{\mathrm{Lo}}\right)$ in these animals (Figure 5A and 5B, respectively). We acknowledge that the correlation between MDSC prevalence and tumor burden is merely associative at this point and further experiments are needed to prove a causal relationship. We speculate the decrease in myeloid infiltration may be related to the inflammatory microenvironment around the tumor [50] since prior studies have shown $\mathrm{A} 1^{-\mathrm{M} / \mathrm{M}}$ or DKO macrophages exhibit increased apoptosis and decreased migration into inflammatory settings [51]. It is also notable that Hedrick and colleagues similarly recently observed a lower frequency of macrophage infiltration into MB49 tumors in $\mathrm{G} 1^{-\mathrm{M} / \mathrm{M}}$ mice, as well as enhanced macrophage apoptosis in "western"-type diet fed $\mathrm{Abcg1} 1^{-/}$MB49 tumor bearing mice [24]. On a chow diet, ABCA1 and ABCG1 protein expression was shown to be reduced by $>95 \%$ in macrophages from DKO [2]. DKO monocytes are reported to show $>80 \%$ reduction in $\mathrm{ABCA} 1$ and $\mathrm{ABCG} 1$, whereas in neutrophils there was a $>50 \%$ reduction in $\mathrm{ABCA} 1$, but no significant reduction in ABCG1 mRNA [2]. This may explain the synergistic reduction in monocytic MDSCs (Ly-6G ${ }^{\text {neg }} \mathrm{Ly}-6 \mathrm{C}^{\mathrm{Hi}}$ ) in tumors from DKO animals (Figure $5 \mathrm{~B}$, lower plot) but not that of granulocytic MDSCs (Ly$6 \mathrm{G}^{+} \mathrm{Ly}-6 \mathrm{C}^{\mathrm{Lo}}$ ) (Figure 5B, top plot). Additional factors may be influencing MDSC numbers in tumors from DKO animals. For example, it has been shown that $L d l r$ - mice transplanted with DKO bone marrow displayed neutrophilia on chow diet and monocytosis in addition to enhanced neutrophilia on western-type diet [2]. In the present study however, tumor bearing myeloid DKO animals did not exhibit statistically significant increased circulating levels of monocytes or neutrophils (Table 1). This discrepancy may be due to differences in genetic background ( $\left.L d l r^{-/}\right)$, diet (Western vs chow), or tumordriven effects in our study versus the previously published report [2]. Interestingly, we observed a significant increase in splenic CD $11 b^{+}, \mathrm{CD}_{11} \mathrm{~b}^{+} \mathrm{GR} 1^{+}, \mathrm{Ly}-6 \mathrm{G}^{\mathrm{neg}} \mathrm{Ly}-6 \mathrm{C}^{\mathrm{Hi}}$ and Ly-6G $\mathrm{G}^{+}$Ly-6C ${ }^{\mathrm{Lo}}$ cells in DKO (Figure 6), arguing against defective migration as the sole underlying cause for lower frequency of MDSCs in tumors from DKO mice. Increased apoptosis in receptor null myeloid cells [51, $52]$ is another potential contributor to the lower observed MDSC levels in receptor null animals. In contrast, A1 $\mathrm{M} / \mathrm{M}$ tumor bearing animals had significantly reduced levels of blood monocytes and neutrophils (Table 1), a trend that was not reflected in the spleen (Figure 6). It is thus plausible that in $\mathrm{A} 1^{-\mathrm{M} / \mathrm{M}}$ animals MDSCs may not accumulate in the tumor bed in part because of lower levels of circulating monocytic immune cells.

Our present studies add to the growing support for the notion that loss of ABCA1 and ABCG1 in myeloid cells modulates tumorigenesis through impacting the immune system. They also have several limitations worth noting. The observation that animals with myeloid deficiency of ABCA1 (A1 $\left.1^{-\mathrm{M} / \mathrm{M}}\right)$ and or ABCG1 $\left(\mathrm{G} 1^{-\mathrm{M} / \mathrm{M}}\right)$ transporters had smaller B16F10 tumors and reduced accumulation of tumor-infiltrating MDSCs is, at present, only associative. Further investigation into the role of MDSCs in mediating the observed influence of myeloid Abcal gene in tumorigenesis are needed to prove a specific role of this cell type in the observed effects on tumor growth. While the underlying mechanism of action by these cholesterol transporter proteins remain to be fully understood, it is of interest to note that previous reports have shown that modulating cholesterol levels at the plasma membrane, either biochemically or through the deletion of cholesterol transporters, can impact immune cell function and phenotype through changes in cellular signaling $[2,16,24,27,28]$. Thus, loss of ABCA1/ABCG1 in our experimental setting may have altered macrophage signaling, as previously shown in $\mathrm{Abcal}^{-/}, \mathrm{Abcgl}^{-/}$or DKO macrophages [16]. For example, heightened TLR signaling is associated with deletion of the cholesterol transporters [16], and TLR signaling has been shown to play a crucial role in initiation of innate immune responses against cancer and subsequent induction of adaptive immune responses [53]. The role of TLR signaling in the present studies remain to be explored. It is reported that TLR signaling in both tumor cells and host immune cells is complex, with both potential pro-tumorigenic advantages to tumor cells and anti-tumor immunogenic immune cell responses to endogenous tumor-generated TLR ligands [54-56]. In addition to changing the immune cell phenotype, altered signaling in receptor-null immune cells may also affect the migration of these cells and their ability to home in to the tumor. One can also speculate that reduced MDSC accumulation in tumors from receptornull animals may thus in part be explained by defective 'homing', as well as enhanced apoptosis [24, 51]. In normal inflammatory settings, apoA-I/HDL suppresses inflammatory responses in macrophages [57-59]. In the tumor microenvironment, apoA-I/HDL appears to promote inflammation by inducing the accumulation of M1-like pro-inflammatory TAMs that have anti-tumor activity [1]. The molecular basis for this shift in TAM phenotype in tumor-bearing mice is under further investigation, but in essence it is similar to our present observations for the myeloid-deleted transporters and those reported by Hedrick and colleagues [24]. Thus, it appears that the loss of ABCA1/ABCG1 in myeloid cells "hard-wires" these immune cells to become pro-inflammatory.

In conclusion, our present study adds to an emerging theme that cholesterol metabolism and tumor immunity are closely linked. Multiple clinical studies have shown an inverse association between circulating HDLc or apoA-I levels and cancer risk [31-38]. Furthermore, studies with liver X receptor (LXR) antagonists resulting in immune cell cholesterol accumulation indicate increased dendritic cell infiltration into tumors with beneficial effects [60, 61]. Most recently, apoA-I and myeloid ABCG1 have been shown to influence the anti-tumor function of 
immune cells $[1,24]$. In the present studies, inhibiting cholesterol efflux pathways globally with SR-B1, or more specifically in myeloid cells by alternative approaches, including targeted deletion of the transporters ABCA1 alone, or ABCA1 in combination with ABCG1, resulted in significant reduction in tumor growth, and accompanying reduction in frequency of the immunosuppressive and tumor-promoting MDSCs. Further studies exploring both the mechanisms linking myeloid cholesterol transport and immune protection against cancer, and the anti-tumor potential of therapies that target immune cell cholesterol content, seem warranted.

\section{MATERIALS AND METHODS}

\section{Materials and general procedures}

All chemicals were from Sigma Chemical (St. Louis, MO) and all solvents were HPLC grade unless otherwise indicated. All mouse studies were performed under protocols approved by the Institutional Animal Care and Use Committee at the Cleveland Clinic.

\section{Mice}

Scavenger receptor class B, type 1 null $\left(\right.$ Scarb1 $\left.^{-/}\right)$ mice used were back-crossed onto a C57BL/6J background for $>>10$ generations. LysM-Cre Abcal $1^{-M /-M}$ $A b c g 1^{+/+}$mice (referred to as $\mathrm{A} 1^{-\mathrm{M} /-\mathrm{M}}$ in this study) were provided by Dr. John Parks (Wake Forest University). Drs. Marit Westerterp and Alan Tall (Columbia University) provided LysM-Cre Abcal ${ }^{-M /-M} A b c g 1^{-M / M}$ mice (referred to as DKO in this study). LysM-Cre Abcg $1^{-M / M}$ (referred to as $\mathrm{G} 1^{-\mathrm{M} / \mathrm{M}}$ in this study) was bred out of DKO in our mouse facility by initially crossing the DKO with WT (LysM-Cre $\mathrm{Abcal}^{+/+} \mathrm{Abcg1^{+/+ }}$ ) to obtain $\mathrm{LysM}$-Cre $\mathrm{Abca1^{+/+ }} \mathrm{Abcg}^{-\mathrm{M} /+}$ and then crossing these animals together to obtain homozygous floxed Abcgl (LysM-Cre Abcal ${ }^{+/+} \mathrm{Abcgl}$ $\left.{ }^{M /-M}\right)$. Both myeloid-deleted ABC-transporter strains were backcrossed onto a C57BL/6J background for $>>10$ generations. $\mathrm{C} 57 \mathrm{BL} / 6 \mathrm{~J}$ mice (referred to as wild type (WT)) were $\mathrm{LysM}$-Cre $\mathrm{Abca1^{+/+ }} \mathrm{Abcg1^{+/+ }}$ and were provided by Dr. John Parks. All mice were bred at Cleveland Clinic's Biological Research Unit (BRU).

\section{Tumor cell lines}

Mouse tumor cell line B16F10 melanoma was obtained from American Type Culture Collection (CRL-6475, ATTC, Bethesda, MD) and MB49 bladder cancer cells were a gift from Ernest Borden (Cleveland Clinic) and were established in 1979 following dimethylbenzanthracene treatment of C57BL/6J mice. Tumor cells were cultured in DMEM supplemented with $10 \%$ heat-inactivated fetal calf serum (FCS), 2 $\mathrm{mM}$ L-glutamine and antibiotic/antimycotic (Invitrogen,
Grand Island, $\mathrm{NY}$ ) at $37^{\circ} \mathrm{C}$ and $5 \% \mathrm{CO}_{2}$ in a humidified atmosphere. Cells used were mycoplasma-negative as determined by direct and indirect testing in the Cleveland Clinic Cell Culture Core.

\section{In vivo tumor studies}

Animals (B16F10 tumor experiments: 2-3 month old male \& female (Scarb1); 3-4 month old female (WT, $\mathrm{A} 1^{-\mathrm{M} / \mathrm{M}}, \mathrm{G} 1^{-\mathrm{M} / \mathrm{M}}$ and $\left.\mathrm{DKO}\right)$ and MB49 bladder cancer experiments: 6-7 month old males (WT, A1 $1^{-\mathrm{M} / \mathrm{M}}$, and DKO)) were inoculated subcutaneously on both flanks with $10^{5}$ tumor cells (in DMEM) per site. Tumor volume, based on caliper measurements, was calculated 3 times a week according to the ellipsoid volume formula: tumor volume $=(\text { the shortest diameter })^{2} \mathrm{x}$ the largest diameter $\mathrm{x}$ 0.525 . Tumor volume is expressed as mean value where $\mathrm{n}=$ number of tumor inoculation sites (two per animal).

\section{Flow cytometry}

Splenocytes, were isolated by mechanical disruption. Individual spleens were cut into small pieces with sterile razor blade in cold RPMI medium and gently pressed through a $70 \mu \mathrm{m}$ cell strainer using the rubber end of a syringe plunger. Cells were collected by centrifugation (300 x g, $7 \mathrm{~min}$ at $4^{\circ} \mathrm{C}$ ) before being lysed for RBCs (LCK lysis buffer; A10492, Invitrogen). Individual tumors were chopped and digested using a tumor dissociation kit (130096-730, Miltenyi Biotec Inc, San Diego, CA, USA) and the mouse impTumor-02 program of the gentleMACS dissociator (Miltenyi Biotec Inc, San Diego, CA, USA) according to manufacturer's protocol. Cells were lysed for RBC before surface staining. Fluorochrome-conjugated antibodies used were as follows: CD11b (CD11b-PE, clone M1/70, 12-0112, CD11b-FITC, clone M1/70, 110112, eBioscience), GR1 (GR1-AF700, clone RB6-8C5, 557979, BD Pharmingen), Ly-6C (Ly-6C-APC, clone AL21, 560595, BD Pharmingen), Ly-6G (Ly-6G-PE, clone 1A8, 551461, BD Pharmingen), F4/80 (F4/80-FITC, clone BM8, 11-4801, eBioscience), CD45 (CD45 VioGreen; clone 30F11.1, 130-097-294, Miltenyi Biotec), CD3 (CD3-AF700, clone 17A2, 561388, BD Pharmingen), CD4 (CD4-FITC, clone RM4-5, 11-0042, eBioscience), CD8a (CD8a-PerCP, clone 53-6.7, BD Pharmingen). Cells were gated on Live (Live/Dead Violet, L34955, Invitrogen), were acquired on a BD LSR II FACS machine and data analyzed using FlowJo software (Treestar Inc., Ashland, OR).

\section{Lipid and complete blood count analyses}

Blood was obtained by cardiac puncture at the time of sacrifice. Whole blood was run undiluted on an Advia 120 hematology system (Siemens Medical Solutions Malvern, PA, USA) for complete blood counts 
and differentials. For total cholesterol, and HDLc levels, EDTA-plasma was prepared and analyzed on a Roche c311 clinical autoanalyzer in a CAP and CLIA accredited reference laboratory in the Center for Cardiovascular Diagnostics and Prevention at the Cleveland Clinic.

\section{Statistical analysis}

For tumor growth, error bars represent standard error of the mean (SEM). For CBC (Table 1) values are expressed as mean \pm SEM. One way ANOVA (Analysis of variance) was used to analyze data across three or four genetic groups. Statistical differences between two groups were assessed by Student's $t$-test whereby a probability value of $p<0.05$ was considered significant.

\section{Author contributions}

MZ performed the majority of the experiments with assistance from DL. JB and MW were involved in animal studies. JSP, ART and MW provided experimental assistance and analyses. MZ, JAD, and SLH designed experiments and wrote the manuscript. All authors critically reviewed and edited the manuscript.

\section{ACKNOWLEDGMENTS}

We thank the Flow Cytometry and the Tumor Biology Core at the Lerner Research Institute. This study was supported by National Institutes of Health grants R01HL128300 and P01HL076491, (SLH), and R01HL119962 (JSP).

\section{CONFLICTS OF INTEREST}

The authors declare no conflicts of interest.

\section{REFERENCES}

1. Zamanian-Daryoush M, Lindner D, Tallant TC, Wang Z, Buffa J, Klipfell E, Parker Y, Hatala D, Parsons-Wingerter P, Rayman P, Yusufishaq MS, Fisher EA, Smith JD, et al. The cardioprotective protein apolipoprotein A1 promotes potent anti-tumorigenic effects. J Biol Chem. 2013; 288: 21237-52.

2. Westerterp M, Murphy AJ, Wang M, Pagler TA, Vengrenyuk Y, Kappus MS, Gorman DJ, Nagareddy PR, Zhu X, Abramowicz S, Parks JS, Welch C, Fisher EA, et al. Deficiency of ATP-binding cassette transporters A1 and G1 in macrophages increases inflammation and accelerates atherosclerosis in mice. Circ Res. 2013; 112: 1456-65.

3. Yvan-Charvet L, Pagler T, Gautier EL, Avagyan S, Siry RL, Han S, Welch CL, Wang N, Randolph GJ, Snoeck HW, Tall AR. ATP-binding cassette transporters and HDL suppress hematopoietic stem cell proliferation. Science. 2010; 328: 1689-93.

4. Yvan-Charvet L, Ranalletta M, Wang N, Han S, Terasaka N, Li R, Welch C, Tall AR. Combined deficiency of $\mathrm{ABCA} 1$ and $\mathrm{ABCG} 1$ promotes foam cell accumulation and accelerates atherosclerosis in mice. J Clin Invest. 2007; 117: 3900-8

5. Oram JF, Lawn RM, Garvin MR, Wade DP. ABCA1 is the cAMP-inducible apolipoprotein receptor that mediates cholesterol secretion from macrophages. J Biol Chem. 2000; 275: 34508-11.

6. Wang N, Silver DL, Costet P, Tall AR. Specific binding of ApoA-I, enhanced cholesterol efflux, and altered plasma membrane morphology in cells expressing $\mathrm{ABC} 1$. J Biol Chem. 2000; 275: 33053-8.

7. Kennedy MA, Barrera GC, Nakamura K, Baldan A, Tarr P, Fishbein MC, Frank J, Francone OL, Edwards PA. ABCG1 has a critical role in mediating cholesterol efflux to HDL and preventing cellular lipid accumulation. Cell Metab. 2005; 1: 121-31.

8. Nakamura K, Kennedy MA, Baldan A, Bojanic DD, Lyons $\mathrm{K}$, Edwards PA. Expression and regulation of multiple murine ATP-binding cassette transporter G1 mRNAs/ isoforms that stimulate cellular cholesterol efflux to high density lipoprotein. J Biol Chem. 2004; 279: 45980-9.

9. Wang N, Lan D, Chen W, Matsuura F, Tall AR. ATP-binding cassette transporters G1 and G4 mediate cellular cholesterol efflux to high-density lipoproteins. Proc Natl Acad Sci U S A. 2004; 101: 9774-9.

10. Christiansen-Weber TA, Voland JR, Wu Y, Ngo K, Roland BL, Nguyen S, Peterson PA, Fung-Leung WP. Functional loss of ABCA1 in mice causes severe placental malformation, aberrant lipid distribution, and kidney glomerulonephritis as well as high-density lipoprotein cholesterol deficiency. Am J Pathol. 2000; 157: 1017-29.

11. McNeish J, Aiello RJ, Guyot D, Turi T, Gabel C, Aldinger C, Hoppe KL, Roach ML, Royer LJ, de Wet J, Broccardo C, Chimini G, Francone OL. High density lipoprotein deficiency and foam cell accumulation in mice with targeted disruption of ATP-binding cassette transporter-1. Proc Natl Acad Sci U S A. 2000; 97: 4245-50.

12. Bodzioch M, Orso E, Klucken J, Langmann T, Bottcher A, Diederich W, Drobnik W, Barlage S, Buchler C, PorschOzcurumez M, Kaminski WE, Hahmann HW, Oette K, et al. The gene encoding ATP-binding cassette transporter 1 is mutated in Tangier disease. Nat Genet. 1999; 22: 347-51.

13. Brooks-Wilson A, Marcil M, Clee SM, Zhang LH, Roomp K, van Dam M, Yu L, Brewer C, Collins JA, Molhuizen $\mathrm{HO}$, Loubser O, Ouelette BF, Fichter K, et al. Mutations in $\mathrm{ABC} 1$ in Tangier disease and familial high-density lipoprotein deficiency. Nat Genet. 1999; 22: 336-45.

14. Lawn RM, Wade DP, Garvin MR, Wang X, Schwartz K, Porter JG, Seilhamer JJ, Vaughan AM, Oram JF. The 
Tangier disease gene product ABC1 controls the cellular apolipoprotein-mediated lipid removal pathway. J Clin Invest. 1999; 104: R25-31.

15. Rust S, Rosier M, Funke H, Real J, Amoura Z, Piette JC, Deleuze JF, Brewer HB, Duverger N, Denefle P, Assmann G. Tangier disease is caused by mutations in the gene encoding ATP-binding cassette transporter 1 . Nat Genet. 1999; 22: 352-5.

16. Yvan-Charvet L, Welch C, Pagler TA, Ranalletta M, Lamkanfi M, Han S, Ishibashi M, Li R, Wang N, Tall AR. Increased inflammatory gene expression in ABC transporter-deficient macrophages: free cholesterol accumulation, increased signaling via toll-like receptors, and neutrophil infiltration of atherosclerotic lesions. Circulation. 2008; 118: 1837-47.

17. Tang C, Liu Y, Kessler PS, Vaughan AM, Oram JF. The macrophage cholesterol exporter ABCA1 functions as an anti-inflammatory receptor. J Biol Chem. 2009; 284: 32336-43.

18. Guo L, Song Z, Li M, Wu Q, Wang D, Feng H, Bernard P, Daugherty A, Huang B, Li XA. Scavenger Receptor BI Protects against Septic Death through Its Role in Modulating Inflammatory Response. J Biol Chem. 2009; 284: 19826-34.

19. Lee BH, Taylor MG, Robinet P, Smith JD, Schweitzer J, Sehayek E, Falzarano SM, Magi-Galluzzi C, Klein EA, Ting AH. Dysregulation of cholesterol homeostasis in human prostate cancer through loss of ABCA1. Cancer Res. 2013; 73: 1211-8.

20. Smith B, Land H. Anticancer activity of the cholesterol exporter ABCA1 gene. Cell Rep. 2012; 2: 580-90.

21. Danilo C, Gutierrez-Pajares JL, Mainieri MA, Mercier I, Lisanti MP, Frank PG. Scavenger receptor class B type I regulates cellular cholesterol metabolism and cell signaling associated with breast cancer development. Breast Cancer Res. 2013; 15: R87.

22. Gabrilovich DI, Ostrand-Rosenberg S, Bronte V. Coordinated regulation of myeloid cells by tumours. Nat Rev Immunol. 2012; 12: 253-68.

23. Youn JI, Nagaraj S, Collazo M, Gabrilovich DI. Subsets of myeloid-derived suppressor cells in tumor-bearing mice. J Immunol. 2008; 181: 5791-802.

24. Sag D, Cekic C, Wu R, Linden J, Hedrick CC. The cholesterol transporter ABCG1 links cholesterol homeostasis and tumour immunity. Nat Commun. 2015; 6: 6354 .

25. Rigotti A, Trigatti BL, Penman M, Rayburn H, Herz J, Krieger M. A targeted mutation in the murine gene encoding the high density lipoprotein (HDL) receptor scavenger receptor class B type I reveals its key role in HDL metabolism. Proc Natl Acad Sci U S A. 1997; 94: 12610-5.

26. Francone OL, Royer L, Boucher G, Haghpassand M, Freeman A, Brees D, Aiello RJ. Increased cholesterol deposition, expression of scavenger receptors, and response to chemotactic factors in Abca1-deficient macrophages. Arterioscler Thromb Vasc Biol. 2005; 25: 1198-205.

27. Koseki M, Hirano K, Masuda D, Ikegami C, Tanaka M, Ota A, Sandoval JC, Nakagawa-Toyama Y, Sato SB, Kobayashi T, Shimada Y, Ohno-Iwashita Y, Matsuura F, et al. Increased lipid rafts and accelerated lipopolysaccharide-induced tumor necrosis factor-alpha secretion in Abca1-deficient macrophages. J Lipid Res. 2007; 48: 299-306.

28. Zhu X, Lee JY, Timmins JM, Brown JM, Boudyguina E, Mulya A, Gebre AK, Willingham MC, Hiltbold EM, Mishra N, Maeda N, Parks JS. Increased cellular free cholesterol in macrophage-specific Abca1 knock-out mice enhances proinflammatory response of macrophages. J Biol Chem. 2008; 283: 22930-41.

29. Haghpassand M, Bourassa PA, Francone OL, Aiello RJ. Monocyte/macrophage expression of ABCA1 has minimal contribution to plasma HDL levels. J Clin Invest. 2001; 108: $1315-20$.

30. Trowbridge IS, Thomas ML. CD45: an emerging role as a protein tyrosine phosphatase required for lymphocyte activation and development. Annu Rev Immunol. 1994; 12: 85-116.

31. Ahn J, Lim U, Weinstein SJ, Schatzkin A, Hayes RB, Virtamo J, Albanes D. Prediagnostic total and high-density lipoprotein cholesterol and risk of cancer. Cancer Epidemiol Biomarkers Prev. 2009; 18: 2814-21.

32. Jafri H, Alsheikh-Ali AA, Karas RH. Baseline and on-treatment high-density lipoprotein cholesterol and the risk of cancer in randomized controlled trials of lipidaltering therapy. J Am Coll Cardiol. 2010; 55: 2846-54.

33. Kozak KR, Amneus MW, Pusey SM, Su F, Luong MN, Luong SA, Reddy ST, Farias-Eisner R. Identification of biomarkers for ovarian cancer using strong anion-exchange ProteinChips: potential use in diagnosis and prognosis. Proc Natl Acad Sci U S A. 2003; 100: 12343-8.

34. Zhang Z, Bast RC Jr, Yu Y, Li J, Sokoll LJ, Rai AJ, Rosenzweig JM, Cameron B, Wang YY, Meng XY, Berchuck A, Van Haaften-Day C, Hacker NF, et al. Three biomarkers identified from serum proteomic analysis for the detection of early stage ovarian cancer. Cancer Res. 2004; 64: 5882-90.

35. Kozak KR, Su F, Whitelegge JP, Faull K, Reddy S, FariasEisner R. Characterization of serum biomarkers for detection of early stage ovarian cancer. Proteomics. 2005; 5: 4589-96.

36. Moore LE, Fung ET, McGuire M, Rabkin CC, Molinaro A, Wang Z, Zhang F, Wang J, Yip C, Meng XY, Pfeiffer RM. Evaluation of apolipoprotein A1 and posttranslationally modified forms of transthyretin as biomarkers for ovarian cancer detection in an independent study population. Cancer Epidemiol Biomarkers Prev. 2006; 15: 1641-6.

37. Clarke CH, Yip C, Badgwell D, Fung ET, Coombes KR, Zhang Z, Lu KH, Bast RC Jr. Proteomic biomarkers apolipoprotein A1, truncated transthyretin and connective 
tissue activating protein III enhance the sensitivity of CA125 for detecting early stage epithelial ovarian cancer. Gynecol Oncol. 2011; 122: 548-53.

38. Kim YW, Bae SM, Lim H, Kim YJ, Ahn WS. Development of multiplexed bead-based immunoassays for the detection of early stage ovarian cancer using a combination of serum biomarkers. PLoS One. 2012; 7: e44960.

39. Su F, Kozak KR, Imaizumi S, Gao F, Amneus MW, Grijalva V, Ng C, Wagner A, Hough G, Farias-Eisner G, Anantharamaiah GM, Van Lenten BJ, Navab M, et al. Apolipoprotein A-I (apoA-I) and apoA-I mimetic peptides inhibit tumor development in a mouse model of ovarian cancer. Proc Natl Acad Sci U S A. 2010; 107: 19997-20002.

40. Tall AR, Yvan-Charvet L, Terasaka N, Pagler T, Wang N. HDL, ABC transporters, and cholesterol efflux: implications for the treatment of atherosclerosis. Cell Metab. 2008; 7: 365-75.

41. Rader DJ, Tall AR. The not-so-simple HDL story: Is it time to revise the HDL cholesterol hypothesis? Nat Med. 2012; 18: 1344-6.

42. Acton S, Rigotti A, Landschulz KT, Xu S, Hobbs HH, Krieger M. Identification of scavenger receptor SR-BI as a high density lipoprotein receptor. Science. 1996; 271: 518-20.

43. Kozarsky KF, Donahee MH, Rigotti A, Iqbal SN, Edelman ER, Krieger M. Overexpression of the HDL receptor SR-BI alters plasma HDL and bile cholesterol levels. Nature. 1997; 387: 414-7.

44. Feng H, Guo L, Wang D, Gao H, Hou G, Zheng Z, Ai J, Foreman O, Daugherty A, Li XA. Deficiency of scavenger receptor BI leads to impaired lymphocyte homeostasis and autoimmune disorders in mice. Arterioscler Thromb Vasc Biol. 2011; 31: 2543-51.

45. Ji Y, Jian B, Wang N, Sun Y, Moya ML, Phillips MC, Rothblat GH, Swaney JB, Tall AR. Scavenger receptor BI promotes high density lipoprotein-mediated cellular cholesterol efflux. J Biol Chem. 1997; 272: 20982-5.

46. Ji A, Meyer JM, Cai L, Akinmusire A, de Beer MC, Webb NR, van der Westhuyzen DR. Scavenger receptor SR-BI in macrophage lipid metabolism. Atherosclerosis. 2011; 217: 106-12.

47. Cai L, Wang Z, Meyer JM, Ji A, van der Westhuyzen DR. Macrophage SR-BI regulates LPS-induced proinflammatory signaling in mice and isolated macrophages. J Lipid Res. 2012; 53: 1472-81.

48. Zhu X, Owen JS, Wilson MD, Li H, Griffiths GL, Thomas MJ, Hiltbold EM, Fessler MB, Parks JS. Macrophage ABCA1 reduces MyD88-dependent Toll-like receptor trafficking to lipid rafts by reduction of lipid raft cholesterol. J Lipid Res. 2010; 51: 3196-206.

49. Zhu X, Westcott MM, Bi X, Liu M, Gowdy KM, Seo J, Cao Q, Gebre AK, Fessler MB, Hiltbold EM, Parks JS. Myeloid cell-specific ABCA1 deletion protects mice from bacterial infection. Circ Res. 2012; 111: 1398-409.

50. Mantovani A, Allavena P, Sica A, Balkwill F. Cancer-related inflammation. Nature. 2008; 454: 436-44.

51. Yvan-Charvet L, Pagler TA, Seimon TA, Thorp E, Welch CL, Witztum JL, Tabas I, Tall AR. ABCA1 and ABCG1 protect against oxidative stress-induced macrophage apoptosis during efferocytosis. Circ Res. 2010; 106: 1861-9.

52. Tarling EJ, Bojanic DD, Tangirala RK, Wang X, LovgrenSandblom A, Lusis AJ, Bjorkhem I, Edwards PA. Impaired development of atherosclerosis in Abcg1-/- Apoe-/- mice: identification of specific oxysterols that both accumulate in Abcg1-/- Apoe-/- tissues and induce apoptosis. Arterioscler Thromb Vasc Biol. 2010; 30: 1174-80.

53. O'Neill LA. When signaling pathways collide: positive and negative regulation of toll-like receptor signal transduction. Immunity. 2008; 29: 12-20.

54. Apetoh L, Ghiringhelli F, Tesniere A, Obeid M, Ortiz C, Criollo A, Mignot G, Maiuri MC, Ullrich E, Saulnier P, Yang H, Amigorena S, Ryffel B, et al. Toll-like receptor 4-dependent contribution of the immune system to anticancer chemotherapy and radiotherapy. Nature Medicine. 2007; 13: 1050-9.

55. Lee $\mathrm{CH}$, Wu CL, Shiau AL. Toll-like receptor 4 signaling promotes tumor growth. J Immunother. 2010; 33: 73-82.

56. Mittal D, Saccheri F, Venereau E, Pusterla T, Bianchi ME, Rescigno M. TLR4-mediated skin carcinogenesis is dependent on immune and radioresistant cells. EMBO J. 2010; 29: 2242-52.

57. Feig JE, Rong JX, Shamir R, Sanson M, Vengrenyuk Y, Liu J, Rayner K, Moore K, Garabedian M, Fisher EA. HDL promotes rapid atherosclerosis regression in mice and alters inflammatory properties of plaque monocyte-derived cells. Proc Natl Acad Sci U S A. 2011; 108: 7166-71.

58. Murphy AJ, Woollard KJ, Hoang A, Mukhamedova N, Stirzaker RA, McCormick SP, Remaley AT, Sviridov D, Chin-Dusting J. High-density lipoprotein reduces the human monocyte inflammatory response. Arterioscler Thromb Vasc Biol. 2008; 28: 2071-7.

59. Sanson M, Distel E, Fisher EA. HDL induces the expression of the M2 macrophage markers arginase 1 and Fizz-1 in a STAT6-dependent process. PLoS One. 2013; 8: e74676.

60. Villablanca EJ, Raccosta L, Zhou D, Fontana R, Maggioni D, Negro A, Sanvito F, Ponzoni M, Valentinis B, Bregni M, Prinetti A, Steffensen KR, Sonnino S, et al. Tumor-mediated liver $\mathrm{X}$ receptor-alpha activation inhibits $\mathrm{CC}$ chemokine receptor-7 expression on dendritic cells and dampens antitumor responses. Nat Med. 2010; 16: 98-105.

61. Westerterp M, Bochem AE, Yvan-Charvet L, Murphy AJ, Wang N, Tall AR. ATP-binding cassette transporters, atherosclerosis, and inflammation. Circ Res. 2014; 114 : 157-70. 